\title{
THE EFFECT OF UNITED STATES LABOR LEGISLATION ON THE FLAG-OF-CONVENIENCE FLEET: REGULATION OF SHIPBOARD LABOR RELATIONS AND REMEDIES AGAINST SHORESIDE PICKETING
}

To meet foreign competition, many unsubsidized American shipowners, primarily importers of petroleum and metallic ores, have registered their vessels in several friendly nations ${ }^{1}$-notably Liberia and Panama ${ }^{2}$ - which exercise little control over ships flying their flags ${ }^{3}$ and charge nominal registration fees. "These American-owned "flag of convenience" vessels," whose ton-

1. Letter From Clarence G. Morse, Federal Maritime Administrator, to the Yale Law Jourral, Oct. 30, 1959, p. 2, on file in Yale Law Library [hereinafter cited as Letter From the Maritime Administrator]. Bulk carriers are not eligible for subsidies. Ibid.

"In light of this wide cost differential [between American and foreign-flag ship operation,] it is an accepted fact that U.S.-flag ships cannot compete on equal terms with foreign-flag ships in foreign trade operations without operating-differential subsidy or some other form of Government aid." Id. at 1 . It has been estimated that the subsidy necessary to keep the required amount of tonnage under the American flag would be $\$ 400$ to $\$ 500$ million yearly more than is now provided. American Committee for Flags of Necessity, Some Important Facts About Flags of Necessity Ships-A Fleet Vital to America's Defense And Economy Simmmary, p. 9 (2d ed. Selvage \& Lee, Inc. [undated]).

2. See Summary of Oceangoing Vessels of 1,000 Gross Tons and Over Owned by United States Companies and Their Affiliates and Registered Under Foreign Flags as of June 30, 1959 [hereinafter cited as Stummary of Oceangoing Vessels], attached to Letter From the Maritime Administrator. Honduran and Venezuelan registry has also been used, but the American-owned tonnage flying these flags is insignificant. See ibid. Costa Rica, which had registered only a negligible number of American-owned vessels, may no longer permit use of its flag as a "flag of convenience." See N.Y. Times, Oct. 31, 1958, p. 57, col. 4 ; id., Nov. 16, 1958, § 1, p. 3, col. 6; Director-General, International. Latouk Office, Reports, 1958-Flag Transfer in Relation to Social Conditions and Safety 6 (Int'l Labour Conf., 41st Sess. 1958). For attempts by other nations to attract flag-ofconvenience shipping, see N.Y. Times, May 27, 1958, p. 62, col. 6 (Lebanon); id., Oct. 30, 1958, p. 61, col. 4 (Tunisia).

3. Apparently, neither state has adopted legislation providing minimum standards of maintenance or requiring periodic inspections. Legislation governing wages and working conditions is very limited in scope. See Goldberg, The Maritine Story: A Study IN LaboR-Managenent Relations 220 (1958) [hereinafter cited as Goldnerg]; International Labour Office, Conditions in Ships Flying the Panamanian Flag 37,39 (1950). The relevant Panamanian legislation is reprinted in id. at 56-64, and in Berguido, The Rights of Seamen on a Ship Under Panamanian Registry, 19 TEMP. L.Q. 458, 46061 (1946). The small Panamanian consular corps would seem unable to enforce the few existing provisions. See InTERnational Labour OFFice, op. cit. supra at 38.

4. "There shall be an initial registration fee of ... one dollar twenty cents per net ton, and there shall be an annual tonnage tax of ten cents per net ton, which taxes shall not be increased during the term of twenty years counted from the date of initial registration." LiberIa CODE tit. 22, $\$ 53$ (1956) ; see Hearings on Vesscl Traissfer, Tradc-In, and Reserve Fleet Policies Before the Subcommittee on the Merchant Marine of the 
nage was small ten years ago, ${ }^{6}$ now total over six million gross tons ${ }^{7}$ and represent approximately thirty-six per cent of all American privately owned, ${ }^{8}$ and approximately five per cent of the world's, merchant tonnage. Flag-ofconvenience registry enables the American shipowner to halve his operating costs ${ }^{10}$ by avoiding requirements that American-flag vessels employ American

Honse Committee on Merchant Marine and Fisheries, 85th Cong., 1st Sess., pt. 2, at 699 (1957) [hereinafter cited as 1957 Hearings] ; S. REp. No. 2494, 81st Cong., 2d Sess. 72 (1950).

While the first widespread use of flags of convenience was apparently to avoid the limitations of the Neutrality Act at the outbreak of World War II, see 6 BEsrepict, ADMIRALty 219-20 (7th ed. 1958) [hereinafter cited as BeNEDict], the present use is for economic reasons. The Maritime Administrator has listed the advantages of foreign transfer as follows: (1) Increased market value of ship; (2) reduced cost of operation, particularly wages; (3) ability to operate in world trade with easy currency conversion; (4) avoidance of U.S. Coast Guard requirements of vessel condition, chespness of repairs abroad; (5) tax savings; and (6) increased tonnage acquirable with the increased earnings made available by delayed taxation. 1957 Hearings pt. 1, at 140; accord, S. REP. No. 2494, 81st Cong., 2d Sess. 66 (1950).

5. This Comment will adopt the term "flag of convenience" since it is more widely used, e.g., N.Y. Times, Jan. 29, 1959, p. 54, col. 6; id., Jan. 4, 1959, § 5, p. 18, col. 4, than the term "flag of necessity" which is favored by shipowners, e.g., Mfemorandum From the American Comm. for Flags of Necessity, Prepared by Donovan, Leisure, Newton \& Irvine, Esqs., to Dep't of State and General Counsel, National Labor Relations Bd., Oet. 30, 1959, or "runaway flag," favored by maritime unions, c.g., $195 \%$ Hearings pt. 2, at 710 (statement of Executive Secretary of the AFL-CIO Afaritime Committee).

6. As of January 3, 1950, 201 merchant vessels, totalling $1,745,048$ gross tons, were registered under the flags of Honduras, Liberia, and Panama although owned by United States interests. See S. REP. No. 2494, 81st Cong., 2d Sess. 174 (1950).

7. See U.S. Maritime Administration, Statistics \& Special Studies Office, Ship Data Branch, Dep't of Commerce, Foreign Flag Vessels Under Effective Control as of July 1, 1959, Aug. 10, 1959 [hereinafter cited as Forcign: Flag Vessels], attached to Letter From the Maritime Administrator. This total is for the 518 ships under "effective" United States control flying the flags of Panama, Liberia, Honduras, and Venczuela. United States companies and their affliates currently own 245 vessels of 1,000 gross tons and over under those flags, totalling 3,529,623 gross tons. Summary of Occangoing Vessels. It appears that the remaining tonnage is accounted for by "vessels owned by forcign companies, the stock of which is owned by American individuals." Letter From the Maritime Administrator, p. 2.

United States companies and their affiliates have also registered 173 ships, totalling $1,923,549$ gross tons, under other flags, particularly those of traditional maritime nations such as Great Britain. See Stmmnary of Occangoing Fessels.

8. In addition to 6,388,000 gross tons flying the flags of Panama, Liberia, Honduras and Venezuela, see Foreign Flag Vessels, American private interests own 9,300,000 gross tons under the American flag, see U.S. Maritrare Adarmistration, Dep't of Cosssesce, Earployarent Report of Unted States-Flag Merchant Fleet Oceanconkg Vessens 1,000 Gross TONS AND Over As OF June 30, 1959, at 5 (1959), and 1,923,549 gross tons under other flags, see Summary of Oceangoing Tressels.

9. As of June 30,1958 , the world's mercliant fleet totalled $118,033,731$ gross tons. Lloyd's Register of Shippiatg, Statistical Tables table I (1958).

10. See 1957 Hearings pt. 1, at 142. 
seamen, ${ }^{11}$ either be repaired in American shipyards or pay a penalty tax of fifty per cent of the value of repairs made abroad, ${ }^{12}$ and undergo periodic Coast Guard inspections requiring high standards of maintenance. ${ }^{10}$ An American flag-of-convenience operator-employing alien crews, ${ }^{14}$ perhaps lowering maintenance standards, and effecting repairs abroad ${ }^{15}$-pays from one-third to one-fifth of American wages ${ }^{10}$ and reduces maintenance and repair bills by about twenty-five per cent. ${ }^{17}$

Corporate tax savings furnish another incentive for flag-of-convenience registry. Liberia refrains from taxing the earnings of corporations whose vessels fly her flag and are not "exclusively engaged in coast-wise Liberian trade."18 Moreover, the United States does not tax the earnings of vesselowning corporations chartered in certain other nations whose ships are doct1mented there. ${ }^{19}$

Arrangements between the United States and the flag-of-convenience nations ${ }^{20}$ coupled with the statutory authority of the executive, during a national emergency, to requisition any vessel "owned by citizens of the United States"21 are designed to ensure control of American-owned flag-of-conven-

11. 49 Stat. 1935 (1936), 46 U.S.C. $\$ 672 \mathrm{a}$ (a) (b) (1952).

12. Rev. Stat. \& 3114 (1875), 19 U.S.C. $\& 257$ (1958); see S. Rep. No. 2494, 81st Cong., $2 \mathrm{~d}$ Sess. 66, 73 (1950).

13. See 1957 Hearings pt. 1 , at 140.

14. See Brief for Plaintiffs (affidavit), Afran Transp. Co. v. National Maritime Union, 169 F. Supp. 416 (S.D.N.Y. 1958).

15. The difference in repair cost estimates between United States and foreign shipyards, using Atlantic coast repair estimates as $100 \%$ is as follows: Belgium-54.60\%; Denmark-49.32\%; France- $65.58 \%$; Germany- $53.78 \%$; Italy- $51.25 \%$; Netherlands51.94\%; Norway-64.16\%; Sweden-57.98\%; United Kingdom-55.04\%. Sec Letter From Maritime Administrator, p. 3.

16. See 1957 Hearings pt. 1, at 142; N.Y. Times, July 23, 1958, p. 54, col. 1; Brief for Appellants, pp. 2-3, Marine Cooks v. Panama S.S. Co., 265 F.2d 780 (9th Cir. 1959). See also American Committee for Flags of Necessity, Some Important Facts About Flags of Necessity Ships-A Fleet Vital to America's Defense and Economy Summary, p. 14 (2d ed. Selvage \& Lee, Inc. [undated]).

17. See 1957 Hearings pt. 1, at 142.

18. See Liberia Cone tit. $35, \S 140$ (c) (1956).

19. See, e.g., Arrangement With Panama Respecting Relief From Double Income Tax on Shipping Profits, Jan. 15, Feb. 8, March 28, 1941, 55 Stat. 1363, 1367, E.A.S. No. 221; Arrangement With Belgium for Reciprocal Relief From Double Income Tax on Shipping Profits, Jan. 28, 1936, 49 Stat. 3871, E.A.S. No. 87.

Most of the large tanker fleets are now operated by Liberian corporations. See Brief for Plaintiffs (affidavit), Afran Transp. Co. v. National Maritime Union, 169 F. Supp. 416 (S.D.N.Y. 1958).

It has been argued that tax savings available to foreign shipowner corporations are the prime cause of flag of convenience fleets. See 1957 Hearings pt. 2, at 699 (cditorial in Jan. 23, 1957, issue of The Shipping World and World Shipbuilding); N.Y. Times, Nov. 5, 1958, p. 70, col. 1. But it seems reasonable to assume that many American shipowners would use flags of convenience even if only labor savings were to be gained by so doing.

20. See 1957 Hearings pt. 1, at 129.

21. 53 Stat. 1255 (1939), 46 U.S.C. § 1242 (1952). 
ience vessels if needed for defense purposes.22 These vessels now constitute one-third of the total privately owned ships considered available for mobilization by the Department of Defense. ${ }^{23}$ Although some were built and initially registered abroad ${ }^{24}$ most were transferred from United States registry pursuant to the Shipping Act, ${ }^{25}$ which makes such transfer unlawful, except that "approval may be accorded either absolutely or upon such conditions as the Secretary [of Commerce] prescribes." Maritime Administrator, to whom the Secretary has delegated his functions, ${ }^{27}$ transfers are freely allowed to shipowners who contract to retain ultimate American ownership and control and to make their ships available to the Government in a national emergency.28

22. ... [U]ntil such time as it may prove feasible for these American shipowners to operate competitively under the United States flag, my Government retains its interest in the continued operation of ships under foreign flags, including the PANLIBHON registries. From our viewpoint there are important and valid defense requirements which support this position.

Statement of Under Secretary of State Dillon to the Intergovernmental Shipping Conference, held in Washington, D.C., June 1959, quoted in Memorandum From American Comm. for Flags of Necessity, supra note 5, at 3; accord, Brief for Plaintiffs (affidavit), p. 4, Afran Transp. Co. v. National Maritime Union, 169 F. Supp. 416 (S.D.N.Y. 1958) (letter from Mr. H. T. Merrill, Chief, Shipping Div., Dep't of State); N.Y. Times, Oct. 17, 1959, p. 46, col. 1 (statement by Vice Admiral R. E. Wilson). See also 1957 Hearings pt. 2, at 631-32 (statement of then Secretary of the Navy Gates).

The Maritime Administration has announced that it would provide United States Government war risk insurance or reinsurance of vessels flying the flags of Panama, Liberia, and Honduras whose corporate owners were majority owned by United States citizens and which had contracted "to make their vessels available to the United States, upon request, in event of national emergency." See N.Y. Times, Dec 3, 1959, p. 73, col. 1.

23. See Letter From the Maritime Administrator, p. 2.

"Mothball" ships are deemed inadequate for emergency requirements because they must be extensively outfitted and reconditioned, a time consuming process, see S. REP. No. 2494, 81st Cong., 2d Sess. 27 (1950) ; 1957 Hearings pt. 2, at 581, 602, 605-07, are less modern than many flag of convenience vessels, compare id. at $\mathbf{5 3 0}$ (most American reserve vessels approximately 17 years old), with U.S. Bureau of tae CENsus, Dep'r of Coumarerce, Statistical Abstract of tae United States 600 (1959) (Liberian merchant fleet has average age of 12 years), and would not provide sufficient tonnage, see 1957 Hearings pt. 2, at 608-09; N.Y. Times, April 18, 1959, p. 12, col. 2.

24. From March 1955 to June 1956, American interests ordered 232 ships, totalling $6,560,835$ deadweight tons, from foreign yards for operation under foreign flags. See 1957 Hearings pt. 2, at 698 (statement of Executive Secretary of AFL-CIO Maritime Committee).

25. Shipping Act of 1916, $\S \S 9,37,41,39$ Stat. 730, as amended, 46 U.S.C. $\S \S 808$, 835,839 (1952).

26. Shipping Act of 1916, § 41, added by 40 Stat 902 (1918), as amended, 46 U.S.C. $\S 839$ (1952). Supervisory powers originally given to the United States Shipping Board were transferred to the United States Miaritime Commission, then to the Secretary of Commerce See Note following 46 U.S.C. $\$ 804$ (1952).

27. See 16 Fed. Reg. 2642-43 (1951).

28. See 46 C.F.R. $\S 221.13$ (1958). Penalties for breach of such contract provisions are severe See ibid.; Shipping Act of 1916, § 41, added by 40 Stat. 902 (1918), as 
But United States maritime unions have actively opposed flag-of-convenience registration. ${ }^{29}$ They point to the reduction in employment on Americanflag ships ${ }^{30}$-from 158,860 in 1945 , to 84,300 in 1951 , to 51,640 in $1958^{\text {a1 }}$ and current unemployment of some 40,500 American seamen, ${ }^{32}$ as proof that

amended, 46 U.S.C. $\$ 839$ (1952) (statutory authority for penalties including forfeiture of the vessel and criminal penalties).

Approval was granted to transfer to foreign ownership and/or registry 354 privatcly owned vessels, totalling 3,246,262 gross tons, in the five year period ending June 30, 1956. 280 of these vessels, comprising $91 \%$ of the total tonnage were destined for Liberian or Panamanian flags. 1957 Hearings pt. 1, at 78. From July 1, 1956, to March 15, 1957, 95 privately owned ships were approved for foreign registry transfer, 82 to Liberia alone. Id. at 27 .

29. "[I]f worse comes to worse in the shipping industry it would be better to scrap our ships than to transfer them to the runaway flags ...." 1957 Hcarings pt. 2, at 710 (statement of Executive Secretary of the AFL-CIO Maritime Committee). "We favor ... any action directed to stop the foreign transfer of more American-flag ships." Id. at 714 (statement of the Executive Secretary-Treasurer of the AFL-CIO Maritime Trades Dep't).

United States governmental support for flag-of-convenience shipping has also raised diplomatic protest from European maritime nations. See N.Y. Times, May 14, 1959, p. 66, col. 1 ; $i d$. ., June 9,1959 , p. 74, col. 5 ; id., June 14, 1959, § 1, p. 88, col. 1. Although wages and operating costs of most American-owned flag-of-convenience vessels seem higher than those on European-owned and -registered ships, see $i d$. ., Nov. 26, 1958, p. 54, col. 5 ; S. REP. No. 2494, 81st Cong., 2d Sess. 70 (1950), the traditional economic advantage of European operators over their American competitors has been diminished, see N.Y. Times, Oct. 17, 1958, p. 57, col. 4; id., March 28, 1958, p. 50, col. 5; id., Aug. 3, 1959, p. 48 , col. 2. In addition, the competitive position of the traditional European maritime nations has been further undermined by non-American flag-of-convenience shipping, sec 1957 Hearings pt. 2, at 694-95; N.Y. Times, Aug. 3, 1959, p. 48, col. 6.

Only the Soviet Union has discriminated against flag-of-convenience ships. Sce N.Y. Times, Aug. 31, 1958, § 5, p. 11, col. 1. See also id., March 23, 1958, § 5, p. 11, col. 5; id., April 13, 1958, § 5, p. 11, col. 2. But similar action by other nations may be presaged by the European-led attempt at the 1958 United Nations Conference on the Law of the Sea to make international recognition of a vessel's nationality dependent upon the existence of a "genuine link" between the ship and the nation of registry. See McDougal, Burke \& Vlasic, The Maintenance of Public Order at Sea and the Nationality of Ships, Nov. 1959, pp. 32-34, 196-201 (manuscript in the Yale Law Library, to be published in the American Journal of International Law for January 1960) (the proposal is of purely economic origin and its implementation would constitute a departure from settled international custom and prevent maximization of beneficial use of the seas); note $86 \mathrm{infra}$.

30. See, e.g., 1957 Hearings pt. 2, at 715.

31. See U.S. Bureau of the Census, Dep't of Commerce, Statistical Abstract of THE UNITED STATES 596 (1959). Employment on American-flag vessels has dropped almost continuously since the Korean war peak, and a net loss of 28,610 jobs has occurred in the last ten years. Ibid. As of October 1, 1959, the estimated pool of licensed and unlicensed seamen employed and available numbered 115,000 men; 66,785 seamen were employed on United States-flag privately owned or operated ships (including turnover), and civil-service seamen on ships of the MSTS Nucleus Fleet (including turnover) numbercd 7,688. See Letter From the Maritime Administrator, p. 5.

32. The estimated number of 40,527 seamen seeking employment includes 25,897 rcgistered at the employment centers for unlicensed personnel of the National Maritime Union, Seafarers International Union, and Sailors Union of the Pacific. Ibid. 
flag-of-convenience shipping is detrimental to American labor. They also claim that growing numbers of flag-of-convenience vessels will depress pay scales and working conditions on vessels still operated under the United States flag by American crews. ${ }^{33}$ The unions have unsuccessfully sought legislation to curtail transfers from United States to foreign registry and to limit the ability of American operators to own or charter foreign-flag vessels. ${ }^{34}$ Perhaps despairing of congressional assistance, the unions have commenced a policy of sporadic picketing of flag-of-convenience vessels entering American ports and have urged other unions to refuse to handle the cargo of such ships. ${ }^{35}$ In December of 1958, the American unions, as part of a world-wide anti-flag-ofconvenience campaign organized by the International Transport Worker's Federation, picketed flag-of-convenience ships in ports throughout the country for a period of four days. ${ }^{36}$ And more recently, the unions have attempted to organize the crews of such vessels and to gain recognition as their bargaining representatives. ${ }^{\mathbf{3 7}}$

\section{Applicability of the Wagner and Taft-Hartley ACts to Labor Relations oN SHipboard}

To aid their organizational drive, the unions have contended that the $\mathrm{Na}$ tional Labor Relations (Wagner) Act and the Labor-MIanagement Relations (Taft-Hartley) Act ${ }^{38}$ should regulate employer-employee relations on board flag-of-convenience ships. ${ }^{39}$ This contention rests upon a literal construction

33. See Hohatan, History of Anrerican Mferchant Seasren 115 (1956); Afran Transp. Co. v. National Maritime Union, 169 F. Supp. 416, 420 (S.D.N.Y. 1958); Brief for Appellants, p. 9, Marine Cooks v. Panama S.S. Co., 265 F.2d 780 (9th Cir. 1959).

34. See Hearings on S. 3823 Before a Snbcommittee of the Senate Committec ons Interstate and Foreign Conunerce, 81st Cong., 2d Sess. 31, 56, 59-61 (1950); 1957 Hcarings pt. 2, at 685, 715; Hearings on H.R. 6601, 7601, Before the Subcomnillec on Merchant Marine and Fisheries, 86th Cong., 1st Sess. 211-15 (1959) (bill to climinate subsidy for American-flag operators who also operate foreign-flag vessels which compete with an essential American-flag service).

35. See N.Y. Times, Nov. 15, 1958, p. 40, col. 1; NMU Pilut, Nov. 20, 1958, p. 3; Seafarer's Log, Nov. 21, 1958, both reprinted in Brief for Plaintiffs exhibit "B" (affidavit), Afran Transp. Co. v. National Maritime Union, 169 F. Supp. 416 (S.D.N.Y. 1958).

36. See N.Y. Times, Aug. 7, 1958, p. 48, col. 8; id., Oct. 27, 1958, p. 53, col. 5; id., Dec. 2, 1958, p. 1, col. 2; id., Dec. 3, 1958, p. 73, col. 6; id., Dec 4, 1958, p. 78, col. 1. While 12y ships were picketed in American ports, "outside the United States, the federation's efionts appeared to be little more than a mediocre success." Id., Dec. 5, 1958, p. 62, col. 5 .

37. See id., Nov. 19, 1959, p. 78, col. 4; id., Oct. 24, 1959, p. 42, col. 8; id., Uet. 22, 1959, p. 74, col. 8; id., Aug. 3, 1959, p. 48, col. 6; N.Y. Herald Tribune, Oct. 22, 1959 , p. 47 , col. 1 .

38. 49 Stat. 449 (1935), as amended, 61 Stat. 136 (1947), 29 U.S.C. $\S \S 141-87$ (1958).

39. Unions have brought representation proceedings in the following flag-of-convenience cases: Peninsular \& Occidental S.S. Co., 120 N.L.R.B. 1097 (1958); Eastern Shipping Corp., 44 L.R.R.M. 1571 (NLRB, Sept. 21, 1959); West India Fruit \& S.S. Co., No. 15-CA-1454, NLRB, complaint issued April 15, 1959 (see note 78 infra and accumpanying text); Compania Maritima Sansoc, Ltd., 2 CCH LAB. L. REP. If 10081 (4th ed. 1950). The NLRB has, of course, jurisdiction over labor relations on American flag ships. 4 BENEDICT 245 (7th ed. 1958); see NLRB v. Waterman S.S. Corp., 309 U.S. 205 (1940). 
of the acts' jurisdictional provisions, which give the NLRB power to resolve "questions of representation" and to prevent "unfair labor practices" when "commerce" is affected. 40 Commerce is defined to include that "between any foreign country and any State, Territory, or the District of Columbia."41 Hence, only ships which never enter United States ports are specifically excluded from the acts' coverage. In regard to land enterprises, these all-encompassing jurisdictional grants have been interpreted to cover labor relations in the plants or offices of foreign corporations located within the United States, ${ }^{42}$ even when their work forces are alien. ${ }^{43}$

But application of American statutes to labor relations on board foreign oceangoing vessels only transitorially in United States waters presents different problems and must be considered in light of principles of international law. Under settled doctrine, ports and adjacent waters are within the sovereign territory of the coastal state, ${ }^{44}$ which may, therefore, prohibit access by foreign vessels or permit entry only on such conditions as it may choose to impose. ${ }^{45}$ The absolute power of the coastal state is tempered, however, by the demands of comity among nations, which require it to exercise a high degree of self-restraint, particularly in matters involving the "internal economy" of a foreign vessel. ${ }^{40}$

40. National Labor Relations Act $\S \S 9$ (c) (1), 10(a), as amended, 61 Stat. 144, 146 (1947), 29 U.S.C. $\$ \S 159,160$ (1958).

41. National Labor Relations Act $\S 2(6)$, as amended, 61 Stat. 138,29 U.S.C. $\$ 152$ (1958).

42. See Compagnie Generale Transatlantique, 118 N.L.R.B. 1327 (1957); Delta Match Corp., 102 N.L.R.B. 1400 (1953).

43. See Italia Societa per Azioni di Navigazione, 1.18 N.L.R.B. 1113 (1957).

44. A vessel is not viewed as the sovereign territory of any state. See Scharrenberg v. Dollar S.S. Co., 245 U.S. 122 (1917) (alternative holding). Therefore, the principles governing extraterritorial application of United States statutes seem inapposite to the problem of applying the labor acts on board foreign-flag vessels. But sec Memorandum From American Comm. for Flags of Necessity, supra note 5, at 9-14, citing Foley Bros. v. Filardo, 336 U.S. 281 (1949), which involved application of American law in forcign countries.

45. See The Schooner Exchange, 11 U.S. (7 Cranch) 116 (1812) (dictum) (Marshall, C.J.) ; Briggs, Law of Natrons 348 (2d ed. 1952) [hereinafter cited as Briggs]; 2 Hackworth, Digest of International LAW $\$ 112$, at 1-2 (1941) [hereinafter cited as Hackivorth] ; Jessup, LAw of Territorial. Waters and Marutime Jurisdiction 191 (1927) [hereinafter cited as Jessup]; 1 OPPENHEIM, INTERNational Law 460-61 (8th ed. 1955) [hereinafter cited as OpPENHEIM]; U.N. Conference on the Law of the Sea, Report-Convention on the Territorial Sec and the Contiguous Zone pt. 1, § I, art. 1, U.N. Doc. No. A/CONF.13/L.52 (1958). But see Colombos, THE INTERnational LAW OF THE SEA 129 (3d rev. ed. 1954) [hereinafter cited as CoLongos] (coastal states required during peacetime to keep their ports open to foreign shipping).

46. ... [I] $\mathrm{t}$ was found long ago that it would be beneficial to commerce if the local government would abstain from interfering with the internal discipline of the ship, and the general regulation of the rights and duties of the officers and crew towards the vessel or among themselves. And so by comity it came to be generally understood among civilized nations that all matters of discipline and all things done on board which affected only the vessel or those belonging to her, and did not involve 
In determining whether to exercise its sovereign prerogatives, the coastal state must consider its self-interest shared with other nations-an "inclusive" interest-in free commercial navigation in addition to the local interests which it seeks to protect by exercise of jurisdiction-its "exclusive" interests-and the exclusive interests of foreign states. ${ }^{47}$ Regulation which constitutes an unreasonable interference with the internal economy of foreign ships may evoke defensive exercise of jurisdiction by other coastal states, thus subjecting oceangoing vessels to different laws in every port. For example, if a coastal state required that every vessel entering its waters employ a crew consisting entirely of the coastal state's nationals, other states might be forced to respond by comparable legislation, and mutually beneficial world trade would be brought to a virtual standstill.

In addition to this unfavorable impact on a coastal state's inclusive interest in international commerce, any substantial exercise of its jurisdiction may interfere with the exclusive interests of foreign states. A vessel may be the locus of diverse exclusive national interests which can be adversely affected by coastal regulation. The flag state, whose law is recognized as governing the internal economy and order of the vessel, ${ }^{48}$ has an interest in protecting the vessel $^{49}$ and requisitioning it in wartime, ${ }^{50}$ and may be heavily dependent on the revenue produced by the registration fees which it is entitled to collect. ${ }^{\text {or }}$ The state or states of which the ultimate owners of the vessel are citizens have an interest in protecting their nationals' investments. ${ }^{62}$ The state in which the corporate owner of the vessel is incorporated has an interest in the

the peace or dignity of the country, or the tranquility of the port, should be leit by the local government to be dealt with by the authorities of the nation to which the vessel belonged ....

Wildenhus's Case, 120 U.S. 1, 12 (1887) (dictum); see The Ester, 190 Fed. 216, 221

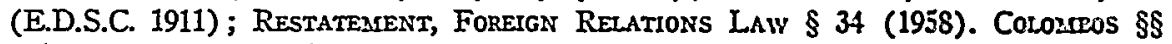
285-86; 1 OppenHetar 503; 2 HackWORTH $\$ 140$, at 209; Rodinson, ADMURALty LAW in THE UNITED STATES $\$ 28$ (1939).

47. See 1 Oppenherm $\S \S 142,25 \%$. See generally MrcDougal \& Burke, Crisis in the Law of the Sea: Comminnity Perspectives Versus National Egoism, 67 YALE L.J. 539 (1958).

48. See St. Clair v. United States, 154 U.S. 134, 152 (1894); Colossros 222-23; Brucgs

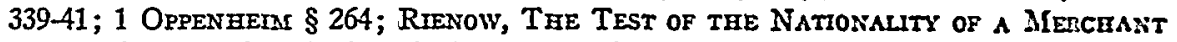
Vesser 5 (1937) [hereinafter cited as Rrenow]; 32 Ops. Atr'y Gen. 332-36 (1920).

49. See 2 HACKworTH $\S 214$; MicDougal, Burke \& Vlasic, supra note 29 , at $82-87$. See also 68 Stat. 883 (1954), 22 U.S.C. $\$ \S 1971-76$ (1958). In addition, the flag state may confer upon its vessels commercial benefits secured by treaty. See RIEsov 3-4; Treaty of Friendship, Commerce and Navigation With Liberia, Aug. 8, 1938, art. xc, 54 Stat. 1745, T.S. No. 956.

50. See Rrenow 7; MoNair, The Requisitioning of Merchant Ships, 27 J. Cosip. LEG. \& INT'L L. (3d ser.) pts. 3 \& 4 at 68, 71-78 (1945) ; MrCDougal, Burke \& Vlasic, supro note 29 , at $93-96$.

51. See N.Y. Times, April 6, 1958, p. 78, col. 1 (fees are $13 \%$ of Liberian national budget).

52. This interest may enable a state to afford the vessel protection even though she is registered elsewhere. See RIENow 104-05; 2 HAckworth $§ 214,757-58$. But sec 1 Opfes:HEIXI 592. 
prosperity of that corporation, even if the stockholders are aliens, since it is a potential source of tax revenue. If the vessel is under charter (particularly a bareboat charter), the state of which the charterer is a national-and perhaps also the state of which the stockholders of a chartering corporation are nationals-has an interest in protecting its nationals' investments in the charter party. The state in which the crew was recruited has an interest in ensuring the continued employment of persons drawn from its labor pool, and the states of which the crew members are citizens have an interest in protecting their nationals. Undue interference by a coastal state with any or several of these interests by disturbing the status quo on shipboard would risk retaliation against the coastal state's own shipping or other interests potentially subject to foreign jurisdiction. ${ }^{53}$

This concurrence of an inclusive interest with various exclusive foreign interests has led the United States to display consiclerable restraint in exercising jurisdiction over foreign-flag vessels. Criminal jurisdiction has been asserted only when the "peace and tranquility" of the port is considered threatened..$^{54}$ And, with few exceptions, civil jurisdiction has been exercised only to provide reasonable protection of interests which are widely recognized as reasonable concerns of all coastal states: collecting fees and taxes for port usage, ${ }^{55}$ enforcing port safety regulations, ${ }^{56}$ protecting the health and welfare of United States residents-primarily by customs, ${ }^{57}$ health, ${ }^{68}$ and security ${ }^{50}$ laws, and regulating health and safety conditions on board vessels carrying passengers, ${ }^{60}$ many of whom are United States nationals or immigrants to this country. The Supreme Court has recognized the demands of comity by a fic-

53. See Romero v. Terminal Operating Corp., 358 U.S. 354, 382-83 (1959) ; Lauritzen v. Larsen, 345 U.S. 571, 582, 592-93 (1953).

54. See Wildenhus's Case, 120 U.S. 1 (1887) ; BrIgGs 350-53; 2 HACKwortri § 140; Colombos $\$ \$ 279,284$; Jessup 145-82; RIENow ch. IX. As to what actions "threaten the peace of the port," see Restatenent, Foreign Relations Law \& 34, comment $b$ (1958). But see 18 U.S.C. $\S \S 2274,2275$ (1958) (defense measures do not require the port's peace to be breached). These statutes make it a crime to tamper with the "motive power" or destroy any private vessel, of American or foreign registry, in United States waters. For convictions under earlier versions of these statutes, see Polonio v. United States, 131 F.2d 679 (9th Cir. 1942); Giugni v. United States, 127 F.2d 786 (1st Cir. 1942); Bersio v. United States, 124 F.2d 310 (4th Cir. 1941). All involved Italian crewmen damaging their ships at the outbreak of World War II on orders from the Italian Government.

55. See Rev. Stat. § 4219 (1875), 46 U.S.C. § 121 (1952); Rev. Stat. § 4225 (1875), 46 U.S.C. § 128 (1952).

56. See Rev. Stat. $\S 4472$ (1875), 46 U.S.C. $\$ 170$ (1952). Enactment of port safety rules is largely left to the discretion of local state and Coast Guard officials. Sec 62 Stat. 249 (1948), 33 U.S.C. § 157 (1952); 26 Stat. 328 (1890), 33 U.S.C. § 147b (1952).

57. See 46 Stat. 747 (1930), 19 U.S.C. $\$ 1581$ (1958); REv. StaT. $\S \S 4197,4200$ (1875), 46 U.S.C. $\$ \S 91,92$ (1952).

58. See 58 Stat. 705 (1944), 42 U.S.C. $\S 269$ (1952). See also 66 Stat. 219 (1952), 8 U.S.C. $\$ \S 1281-87$ (1958) (entry, discharge, and medical treatment in this country, of alien crews on foreign flag vessels regulated).

59. See Note, 28 TEMP. L.Q. 230 (1954).

60. See 22 Stat. 186 (1882), 46 U.S.C. $\$ \S 151-56 a$ (1952); REv. STAT. $§ 4400$ (1875), as amended, 46 U.S.C. $\S 362$ (1952). 
tion that all merchant vessels have an implied consent to enter United States ports. ${ }^{61}$ This consent can be made subject to conditions, the Court has held, only by statutory language which puts foreign vessels on notice prior to their entering American waters. ${ }^{62}$ Such language has seldom been found in statutes which arguably constitute major regulations of the management of foreign vessels. ${ }^{63}$ Congress has interfered with employer-employee relations on foreign vessels through four interrelated statutes ${ }^{\text {of }}$-the "Seamen's Wage" actsapparently enacted to reduce foreign shipowners' competitive advantage by indirectly forcing them to pay higher wages. ${ }^{05}$ The most important ${ }^{00}$ was

61. See Patterson v. Bark Eudora, 190 U.S. 169, 178 (1903); The Schooner Exchange, 11 U.S. (7 Cranch) 116 (1812).

62. A nation would justly be considered as violating its faith, although that faith might not be expressiy plighted, which should suddenly and withuut previous nutice, exercise its territorial powers in a manner not consonant to the usages and received obligations of the civilized world....

....

If, for reasons of state, the ports of a nation . . be closed against . . vessels of any particular nation, notice is usually given of such determination.

Id. at 136, 140; accord, Benz v. Compania Naviera Hidalgo, S.A., 353 U.S. 138, 147 (1957) ; Sandberg v. McDonald, 248 U.S. 185, 195 (1918) ; Cunard S.S. Co. v. Mellon, 262 U.S. 100, 132 (1923) (dissenting opinion).

63. Compare Brown v. Duchesne, 60 U.S. (19 How.) 183 (1857) (patent laws nut applicable on board foreign vessel) ; Petition of Canadian Pac. Ry., 278 Fed. 180 (IV.D. Wash. 1921) (statute requiring that $75 \%$ of crew be able to understand orders in language in which they are given inapplicable); United States v. Ah Fook, 183 Fed. 33 (9th Cir. 1910) (immigration laws), and United States $e x$ rel. Anderson v. Burke, 99 Fed. 895 (C.C.S.D. Ala. 1899) (same), with Cunard S.S. Co. v. Mrellon, 262 U.S. 100 (1923) (18th Amendment and National Prohibition Act, barring the "importation" of intoxicating liquors into "the United States and all territories subject to the jurisdiction thereof for beverage purposes," held to prohibit ships' stores of liquor on foreign-flag vessels in United States waters).

64. REv. StAT. § 4527 (1875), 46 U.S.C. § 594 (1952) (seaman discharged without fault must be paid one month's wages even if not yet earned), Vlavianos v. The Cypress, 171 F.2d 435 (4th Cir. 1948), cert. denied, 337 U.S. 924 (1949) (applicable to forcign seamen on foreign-flag vessel); Rev. STAT. $\$ 4529$ (1875), 46 U.S.C. $\$ 596$ (1952) (provision for immediate payment of seaman after discharge of cargo or of seaman). The Sonderborg, 40 F.2d 652 (E.D. Va. 1930), aff'd, 47 F.2d 723 (4th Cir.), cert. denied sub nom. Alties, Dampskibeselskabet Donnenborg v. Mikkelsen, 284 U.S. 618 (1931) (applicable to foreign seamen on foreign-flag vessel); REv. STAT. $\$ 4530$ (1875), 46 U.S.C. $\$ 597$ (1952) (seamen entitled at every port to part of wages earned but unpaid), Strathearn S.S. Co. v. Dillon, 252 U.S. 348 (1920) (applicable to foreign seamen on foreign-flag vessels); 23 Stat. 55 (1884), 46 U.S.C. § 599 (1952) (wage advances to seamen unlawiul), Heros v. Cockinos, 177 F.2d 570 (4th Cir. 1949) (applicable to advances made in U.S. waters to forcign seamen on foreign-flag vessels); see 6 Benedict 147-48 (7th ed. 1958). See generally GulitBERG 71. See also 66 Stat. 223 (1952), 8 U.S.C. § 1286 (1958) (illegal to discharge alien seaman in the United States without prior approval of Attorney General).

65. See H.R. Rep. No. 645, 62d Cong., 2d Sess. 7 (1912) ; Bickel, Tne Uxpvalusnen Opinions of Mr. Justice Brandeis 47-50 (1957) (unpublished opinion of Brandeis, J., in Strathearn S.S. Co. v. Dillon, 252 U.S. 348 (1920)). But see GordeEe ch. 3 (Congress intended only to protect seamen).

66. Rev. StAT. $\$ 4530$ (1875), 46 U.S.C. $§ 597$ (1952). 
designed to enable dissatisfied alien seamen to jump ship in American ports by giving them the right to collect part of the wages they had already earned immediately, irrespective of the terms of their articles of employment. But applying this legislation, which contains the requisite specificity, to vessels flying foreign flags is not precedent for applying the American labor acts aboard foreign ships. Even under the "Seamen's Wage" statutes, attempts to exclude advance payments made in foreign ports from the amount due were blocked by the Court for lack of specific expression of congressional intent. ${ }^{77}$

In light of these principles and precedents, insufficient congressional authorization exists to extend the labor acts' coverage to all foreign vessels calling at United States ports and thus to expose the bulk of the world's shipping to American union organizing efforts. ${ }^{68}$ The NLRB has, therefore, refused to hear cases involving shipowner-crew relations on board foreign-flag vessels owned by foreigners. Compania Maritima Sansoc, $L t d .^{60}$ affirmed dismissal of a representation petition on the ground that the "internal economy of a vessel of foreign registry and ownership was involved."7o Neither the crew, nor the corporate owner of the Panamanian-flag vessel, nor the majority of its stockholders, were American. ${ }^{11}$ On analogous facts, the NLRB's General Counsel recently refused to issue a complaint against an alleged employer unfair labor practice. ${ }^{2}$

67. See Sandberg v. McDonald, 248 U.S. 185 (1918); Jackson v. S.S. Archimedes, 275 U.S. 463 (1928). By advancing money in foreign ports, often to the employment agent, the shipowners could reduce wages due seamen when they reached America. Sce BickEL, op. cit. supra note 66, at 54-55. Legislation designed to avoid this construction of the advance-payment statute by explicitly applying it to payments made abroad was bitterly protested by foriegn governments, and failed to be enacted. See BrigGs 353; Benz v. Compania Naviera Hidalgo, S.A., 353 U.S. 138 (1957).

38 Stat. 1169 (1915), 46 U.S.C. $\$ 672$ (a) (1952), provides that "no vessel of 100 gross tons and upward ... shall be permitted to depart from any port of the United States unless she has on board a crew of not less than $75 \%$ of which, in each department thereof, arc able to understand any order given by the officers of such vessel ...." (Emphasis added.) This statute has been held inapplicable to foreign vessels. See Petition of Canadian Pac. Ry., 278 Fed. 180 (W.D. Wash. 1921).

68. No legislative history exists indicating that Congress ever considered whether the labor acts should apply to such vessels. The few relevant remarks indicate that Congress was concerned only with the American workingmen. See H.R. REp. No. 245, 80th Cong., 1st Sess. 4 (1947) (remarks of Representative Hartley) ; 75 Cong. Rec. 5465 (1932) (rcmarks of Representative Dyer) ; 75 id. at 5482 (remarks of Representative Blanton). Sec also 22 C.F.R. $\S 81.12$ (1958) ("United States citizens employed on foreign vessels . . . have no claim ... to the special protection, in matters relating to their employment, which the laws of the United States afford seamen employed on vessels of the United States.").

69. Compania Maritima Sansoc, Ltd., 2 CCH LAB. L. REP. I 10081 (4th ed. 1950); sce Sailors' Union (Moore Dry Dock Co.), 92 N.L.R.B. 547, 561 (1950) (subsequent casc).

70. $2 \mathrm{CCH}$ LAB. L. REP. at 10262 .

71. Although the crew was wholly alien, many seamen were recruited and signed articles of employment in the United States.

72. 44 L.R.R.M. 1363 (NLRB July 13, 1959). The case differs slightly from Sansoc since the articles of employment were executed abroad. 
These decisions find support in Benz v. Compania Navicra Hidalgo, S.A., ${ }^{73}$ decided by the Supreme Court in 1957. There, a dispute over wages and working conditions erupted on shipboard between the wholly alien crew and the captain of a Liberian-flag vessel docked in Portland harbor, and American unions picketed in support of the crew. The vessel was owned by a Liberian corporation, whose stockholders were apparently not Amerians. Th The Court held, 7 to 1 , that the NLRB did not have exclusive jurisdiction to grant relief from the picketing and that the federal court was therefore free to award damages as provided by state common law. The Court discussed the issue as being whether the labor acts applied to the shipowner-crew dispute ${ }^{75}$ the cases cited by the Court and on which it relies involve the application of various United States statutes on board foreign-flag vessels. ${ }^{70}$ And even were the issue framed in terms of remedies against picketing, ${ }^{77}$ the absence of exclusive NLRB jurisdiction over this shoreside activity would seem to preclude regulation on shipboard since the latter would result in greater interference with the internal economy of the vessel.

In two recent NLRB cases, however, decisions involving foreign-owned flag-of-convenience vessels have been distinguished and the American labor statutes have been applied on board American-owned flag-of-convenience vessels. In West India Fruit \& S.S. Co., currently pending before the Board, 78 the General Counsel authorized issuance of an unfair labor practice complaint against an American corporation which owned and operated a Liberian-flag vessel manned by a wholly alien crew. ${ }^{79}$ In Peniusular \& Occidental S.S. Co., 80 the Board accepted jurisdiction over representation proceedings on board two Liberian-flag vessels. The Liberian corporate owners were wholly owned subsidiaries of an American corporation, which operated the vessels under bareboat charter. Some of the crew were American citizens or resident aliens, and most of the crew had been recruited and had signed articles of employment in the United States.

These rulings were probably not premised on a theory that the vessels involved were of American nationality, and therefore subject to United States legislation equally with American-flag ships. ${ }^{81}$ The United States, in commer-

73. 353 U.S. 138 (1957).

74. See Record, p. 46.

75. 353 U.S. at $142-43$.

76. The Court cited Cunard S.S. Co. v. Mellon, 262 U.S. 100 (1923); Brown v. Duchesne, 60 U.S. (19 How.) 183 (1857) ; and the "Seamen's Wage" cases, see notes 64-67 sutpra. Wildenhus's Case, 120 U.S. 1 (1887), concerning the exercise of criminal jurisdiction over foreign flag vessels in American ports, was also cited.

77. See notes 125-215 infra and accompanying text.

78. The case is "now under consideration and awaiting final determination by the Board." Letter From Stuart Rothman, General Counsel, NLRB, to the Yale Low Journal, Oct. 13, 1959, on file in Yale Law Library.

79. See ibid.; N.Y. Times, April 16, 1959, p. 65, col. 6.

80. Peninsular \& Occidental S.S. Co., 120 N.L.R.B. 1097 (1958).

81. "No assertion by a State that a vessel belongs to itself bequse the owners are of its nationality, has succeeded." RrENow 217. 
cial treaties with a number of states, including the flag-of-convenience nations Liberia and Honduras, has obligated itself to recognize the documents and maritime flags of these states as conclusive of the nationality of vessels bearing them. ${ }^{82}$ Thus, American courts and the NLRB are barred from denying the foreign nationality of these vessels, despite underlying United States interests in them. Moreover, according to settled international law, a vessel possesses only one nationality ${ }^{83}$ which the maintenance of international public order and navigation require to be readily ascertainable. ${ }^{84}$ Registration, as shown by the ship's documents and flag, is the only means by which nationality may be so ascertained. Therefore, a vessel's registration is universally determinative; all nations are bound once any state has unilaterally attributed its nationality to a vessel. ${ }^{85}$ An attempt to substitute for registration a less objective test of nationality would founder on a diversity of interpretationseach probably based upon the interpreting state's exclusive interests-and could result in the disruption of mutually advantageous commerce. ${ }^{80}$

Nor do cases applying the Jones Act ${ }^{87}$ to tort actions by aliens against foreign-flag shipowners ${ }^{88}$ support, as some would argue, ${ }^{80}$ the Board's appli-

82. See Treaty of Friendship, Commerce, and Navigation With Liberia, Aug. 8, 1938, art. xv, 54 Stat. 1739, T.S. No. 956; Treaty of Friendship, Commerce, and Consular Rights With Honduras, Dec. 7, 1927, art. x, 45 Stat. 2625, T.S. No. 964.

83. See RIENow 13-15; Briggs 330; Colombos 216. No state may grant registration to a ship concurrently registered in another country. See 1 OPPENHEIM 595; RIENow 219; U.N. Conference on the Law of the Sea, Report-Convention on the High Sects art. 6, cl. 2, U.N. Doc. No. A/CONF.13/L.54 \& Add 1 (1958).

84. See McDougal, Burke \& Vlasic, The Maintenance of Public Order at Sea and the Nationality of Ships, Nov. 1959, pp. 2, 76, 111-12.

85. See Rienow 218; Briggs 331 ; Colombos 216.

86. See McDougal, Burke \& Vlasic, supra note 84, at 5-9, 19-20, 32-34.

Hence, the recent United Nations Conference on the Law of the Sea rejected a proposed text, put forward by opponents of flag-of-convenience shipping, which unequivocally stated that recognition of a vessel's nationality requires a "genuine link" between the vessel and the flag state. See RetfF, The United States and the Treaty Law of tue Sea 243 (1959). "Genuine link" was not defined. Instead, the Conference meeting in Geneva on April 29, 1958, adopted a Convention on the High Seas, article 5 of which reads as follows:

1. Each State shall fix the conditions for the grant of its nationality to ships, for the registration of ships in its territory, and for the right to fly its flag. Ships have the nationality of the State whose flag they are entitled to fly. There must exist a genuine link between the State and the ship; in particular, the State must effectively excrcise its jurisdiction and control in administrative, technical and social matters over ships flying its flags.

U.N. Doc. No. A/CONF.13/L.54 \& Add 1 (1958). The Conference thus affirmed the prerogative of any state to fix the conditions of registry and altered the text so as to obscure the significance of "genuine link." For citation to writings by the article's supporters, and for criticism of the article, see McDougal, Burke \& Vlasic, supra at 5-36.

87. 41 Stat. 1007 (1920), 46 U.S.C. \& 688 (1952).

88. E.g., Bartholomew v. Universe Tankships, Inc., 263 F.2d 437 (2d Cir. 1959) ; Gambera v. Bergoty, 132 F.2d 414 (2d Cir. 1942), cert. denied, 319 U.S. 742 (1943). See Gitmore \& Black, Admiralty 388 (1957); Harolds, Some Legal Problems Arising Out of Foreign Flag Operations, 28 FordhaM L. Rev. 295, 310-12 (1959) (discussing cases).

89. See Afran Transp. Co. v. National Maritime Union, 169 F. Supp. 416, 425 (S.D. N.Y. 1958). 
cation of the Wagner and Taft-Hartley Acts on board American-owned fagof-convenience vessels. The Jones Act, by its terms, is applicable to any seaman injured in the course of his employment; ${ }^{00}$ its coverage therefore seems literally as broad as that of the labor acts. Claims under the Jones Act are allowed in United States courts against owners of foreign-flag vessels whenever there are sufficient American "contacts"-such as nationality of owners, situs of injury, country of recruitment or signing of the seamen, nationality or residence of the seamen, and the home port of the vessel ${ }^{01}-\mathrm{a}$ test comparable to that articulated by the NLRB in flag-of-convenience cases. ${ }^{92}$ But courts have extended Jones Act recovery to the crews of foreign-flag vessels on the assumption that a different measure of personal injury recovery does not interfere with the internal economy of the vessel..$^{83}$ Hence, usurpation of applicable tort law does not have an impact on the principles of comity comparable to application of the labor acts. And special humanitarian considerations may motivate a court to allow speedy recovery, under American law, to seamen convalescing in the United States and lacking ready access to a forum in the flag state. ${ }^{94}$ In addition, the courts have been particularly aware of the potential retaliation and disruption of international trade deriving from an over-extension of Jones Act coverage, ${ }^{95}$ a fact that underscores the importance of these factors in limiting the jurisdictional scope of the labor statutes.

On the other hand, the argument that applying American labor legislation on board American-owned flag-of-convenience vessels flying Liberian, Honduran, and Costa Rican flags runs counter to provisions in United States consular and commercial treaties with those nations does not seem meritorious. ${ }^{93}$

90. 41 Stat. 1007 (1920), 46 U.S.C. § 688 (1952).

91. See Lauritzen v. Larsen, 345 U.S. 571 (1953). Compare Airline Stewards v. Trans World Airlines, Inc, 173 F. Supp. 369, 377-78 (S.D.N.Y. 1959) (criteria for determining whether the Railway Labor Act should be applied to foreign commerce).

Two recent opinions, Batholomew v. Universe Tankships, Inc., 263 F.2d 437 (2d Cir. 1959 ) and Bobolakis v. Compania Panamena Maritima San Gerassimo, S.A., 168 F. Supp. 236 (S.D.N.Y. 1958), apparently overruling Miproumeriotis v. Seacrest Shipping Co., 149 F. Supp. 265 (S.D.N.Y. 1957) and Argyros v. Polar Compania De Navegacion, Ltda., 146 F. Supp. 624 (S.D.N.Y. 1956), indicate that underlying American stock ownership is a sufficient contact.

92. See notes 109-10 infra and accompanying text. Compare Fianza Cia. Nav. S.A. v. Benz, 37 CCH Lab. Cas. 66733 (D. Ore. 1958) (Issue of existence of labor dispute between picketing American union on shore and shipowner: "... [W] hat flag any given bottom carries is not of importance. The question is: Who are the true owners, the true operators and the true charterers ....").

93. '... [M] ]atters of 'internal management' are not involved in an action by' a seaman to recover damages for injuries suffered through the negligence of the shipowner." Gerradin v. United Fruit Co., 60 F.2d 927, 929 (2d Cir. 1932) (A.N. Hand, J.).

94. See Gilarore \& Black, Adariralty 390-91 (1957).

95. See, e.g., Romero v. International Terminal Operating Co., 358 U.S. 354 (1959); Lauritzen v. Larsen, 345 U.S. 571 (1953).

96. See Memorandum From the American Committee for Flags of Necessity, Prepared by Donovan, Leisure, Newton \& Irvine, Esqs., to Dep't of State \& General Counsel, National Labor Relations Bd., Oct. 30, 1959, pp. 100-18. The treaties involved are: Treaty of 
Consular and commercial treaties, which have been broadly construed in favor of aliens claiming rights under them, ${ }^{07}$ are self-executing and have the force of congressional enactments. ${ }^{98}$ Although Taft-Hartley was enacted subsequent to the treaties with the flag-of-convenience states, Congress expressed no intent to alter them, and similar treaties signed since enactment of Taft-Hartley ${ }^{99}$ contain no reservations indicating that the act restricts rights under them. It would therefore seem proper to conclude that Congress intended no construction of the labor statutes inconsistent with provisions of these treaties. ${ }^{100}$

But NLRB jurisdiction over activities on board American-owned flag-ofconvenience vessels does not appear to conflict with these treaties. The consular treaty with Liberia provides:

A consular officer shall have exclusive jurisdiction over controversies arising out of the internal order of private vessels of his country, and shall alone exercise jurisdiction in cases, wherever arising, between officers and crews, pertaining to the enforcement of discipline on board, provided the vessel and the persons charged with wrongdoing shall have entered a port within his consular district. Such an officer shall also have jurisdiction over issues concerning the adjustment of wages and the execution of contracts relating thereto provided, however, that such jurisdiction shall not exclude the jurisdiction conferred on local authorities under existing or future laws. ${ }^{101}$

Interpretation of "controversies arising out of the internal order" seems limited to disciplinary matters between captain and crew, ${ }^{102}$ relatively minor crimes on shipboard, ${ }^{103}$ and suits by seamen for certain wage claims. ${ }^{104}$ The

Friendship, Commerce and Navigation With Liberia, Aug. 8, 1938, 54 Stat. 1739, T.S. No. 956; Treaty of Friendship, Commerce and Consular Rights With Honduras, Dec. 7, 1927, 45 Stat. 2618, T.S. No. 964; Treaty of Friendship, Commerce, and Navigation With Costarica, July 10, 1851, 10 Stat. 18, T.S. No. 62; Convention Respecting Consular Officers With Liberia, Oct. 7, 1938, 54 Stat. 1751, T.S. No. 957.

97. See, e.g., Jordan v. Tashiro, 278 U.S. 123 (1928) ; Asakura v. City of Seattle, 265 U.S. 332 (1924); Geofroy v. Riggs, 133 U.S. 258 (1890).

98. See Jordan v. Tashiro, supra note 97; Baldwin v. Franks, 120 U.S. 678, 703.06 (1887) (dissenting opinion of Field, J.) ; BrIGGS 886, 888 (distinction between self-exccuting and non-self-executing treaties).

99. See, e.g., Treaty of Friendship, Commerce and Navigation With the Italian Republic, Feb. 2, 1948, 63 Stat. 2255, T.I.A.S. No. 1965.

100. The Supreme Court has consistently tried to avoid construing statutes and treaties as contradicting, and thus limiting, one another. See, e.g., Cook v. United States, 288 U.S. 102,120 (1933) (Court held that a treaty with Great Britain was not abrogated by the Tariff Act of 1930); United States v. Forty-Three Gallons of Whiskey, 108 U.S. 491,496 (1883).

101. Convention Respecting Consular Officers With Liberiá, Oct. 7, 1938, art. x, para. 1, 54 Stat. 1751, T.S. No. 957.

102. See, e.g., The Wind, 22 F. Supp. 883 (E.D. Pa. 1938). Compare The Binna, 1938 Am. Mar. Cas. 682 (S.D. Tex. 1938), with The Marchen Maersk, 1937 Am. Mar. Cas. 1531 (S.D.N.Y. 1937).

103. See Wildenhus's Case, 120 U.S. 1, 12 (1887).

104. See Papadakis v. S.S. Virginia, 1948 Am. Mar. Cas. 1721 (E.D. Va. 1948) (claims for advances on prior voyages are matters of internal cconomy). 
clause has never successfully been invoked to restrict the jurisdictional scope of United States legislation falling beyond such narrow areas. And the concluding clauses of the first sentence refer specifically to matters of "discipline" and "wrongdoing" in cases between "officers and crew."10s In addition, exclusive consular jurisdiction over "issues concerning the adjustment of wages and the execution of contracts relating thereto" is explicitly made concurrent with applicable laws of the United States. Hence, the treaty would seem to have no bearing on the intended scope of the labor acts, which cover matters over which consuls are not accorded exclusive jurisdiction. The commercial treaty with Liberia grants to Liberian nationals "equally with those of the most-favored nation ... liberty freely to come with their vessels" into United States ports and territorial waters. ${ }^{106}$ It is, therefore, not the vessel herself that is protected by this article. Nevertheless, corporations formed under Liberian law and owning ships which fly the Liberian flag, even when their stockholders are Americans, would come within this clause since the ships are "their vessels." But, although it could be argued that exercise of NLRB jurisdiction erects an inhibitory if not prohibitory barrier to entry and therefore infringes "liberty freely to come," the clause seems primarily designed to ban discriminatory regulation of port usage and discriminatory pilotage or port fees. ${ }^{107}$ Another article of the commercial treaty provides that Liberian vessels shall "in all respects and unconditionally be accorded the same treatment as" the vessels of the United States. ${ }^{108}$ Since all American-flag ships are subject to American labor statutes, this article would not seem to bar application of the acts to flag-of-convenience vessels. While it might be argued that the change in labor relations which application of the acts would cause on board foreign-flag vessels-a change which would not occur on American-flag ships - violates this clause, the change does not result from any difference in treatment of the vessels by the United States Government.

Moreover, selective application of the labor statutes on the basis of ultimate American ownership is less in conflict with the principles of comity than application of the acts to all foreign vessels. Application to a smaller number of ships reduces the burden on the free flow of commerce and thus constitutes a lesser interference with the inclusive interests of all states, including the United States. Limited application also minimizes the interference with exclusive in-

105. Cf. Rev. Stat. $\$ 4079$ (1875), as amended, 22 U.S.C. $\$ 256$ (1958).

106. Treaty of Friendship, Commerce, and Navigation With the Republic of Liberia, Aug. 8, 1938, art. vI, 54 Stat. 1739, 1742, T.S. No. 956. Substantially the same clauses appear in treaties with Honduras and Costa Rica. See Treaty of Friendship, Commerce, and Consular Rights With Honduras, Dec. 7, 1927, art. vr, 45 Stat. 2618, 2622, T.S. No. 964; Treaty of Friendship, Commerce, and Navigation With the Republic of Costarica, July 10, 1851, art. II, 10 Stat. 18, 19, T.S. No. 62.

107. See 6 Benedict 50 (7th ed. 1958); Hawhins, Coararerctal Treatres Asd Agreements: Princtrles and Practice 34 (1951) ; Hebod, Favored Natron Treatarent: A:: Anatysis of the Most Favored Nation Clause 36 (1901).

108. Art. xIv, 54 Stat. at 1745 . No comparable provision exists in the treaties with Honduras and Costa Rica. 
terests of foreign states, thereby lessening the risk of retaliation against American interests. And American ownership diminishes the extent to which exclusive foreign interests in a vessel are invaded.

Nonetheless, selective application of the acts on the basis of factors less objective than registry might lead to undue uncertainty for ship operators, who would be unable to ascertain in advance of entering United States waters whether their relationship with their crews would be subjected to NLRB jurisdiction. The Labor Board's failure in Peninsular \& Occidental S.S. Co. to indicate which of the many factors it cited-such as the nationality of the underlying owners, ${ }^{100}$ place of recruitment of seamen, and their nationalityare indispensable to application of the acts, ${ }^{110}$ manifests this problem. Assertion of NLRB jurisdiction on the basis of obscure and unspecified criteria does violence to the Supreme Court's traditional and desirable rule that foreign-flag vessels should not be subject to conditions of entry without unequivocal prior notice.

More important, principles of comity would seem to proscribe even selective exercise of NLRB jurisdiction. Application of American labor laws would have a far-reaching impact upon the internal economy of a vessel by enabling an American union to organize her crew. After a successful representation election under NLRB auspices, the union could become the crew's bargaining agent, and the shipowner would thereafter have a duty to bargain with it in good faith and to refrain from committing any unfair labor practices. Since the crew's terms or conditions of employment would be covered by existing articles, forcing new terms or conditions prior to the end of the voyage would probably be a mutinous act. ${ }^{111}$ But the crew could demand higher wages and better working conditions at the termination of the voyage when its articles of employment expired. Discharge of crew members by the shipowner in an attempt to resist these demands would constitute an unfair labor practice. ${ }^{112}$

Further, by regulating the internal economy of foreign-flag ships, application of American labor legislation to flag-of-convenience vessels would displace the labor relations policies of the flag states. ${ }^{113}$ The failure of Liberia

109. Uncertainty as to this criterion would not exist in the case of transferred vessels, since the Maritime Administration's requirement of continued American ownership would make a prescription of such ownership plausible. See note 28 supra and accompanying text. But cf. Fianza Cia. Nav. S.A. v. Benz, 37 CCH Lab. Cas. 66733 (D. Ore. 1958) (presumption of foreign ownership).

110. See 120 N.L.R.B. at 1.101 n.7.

111. Cf. Rees v. United States, 95 F.2d 784,.792 (4th Cir. 1938) (indictment for revolt by seamen on United-States-flag ship while in harbor in Uruguay).

112. See National Labor Relations Act $\S 8(\mathrm{a})(1)$, as amended, 61 Stat. 140 (1947), 29 U.S.C. \& 158 (a) (1) (1958).

113. See Evangelinos v. Andreavapor Cia. Nav. S.A., 162 F. Supp. 520 (S.D.N.Y. 1958) (refusal to apply Panamanian labor legislation to labor relations on board Liberianflag vessels owned by Panamanian corporations, on the ground that the law of the flag state - not that of the owner-should be applied absent contractual stipulation to the contrary); Grivas v. Alianza Compania Armadora, 150 F. Supp. 708 (S.D.N.Y. 1957) (same). 
and Panama to enact extensive labor legislation for their flag ships ${ }^{11 *}$ is an expression of a policy to leave shipowner-crew relations to private parties. Pursuant to this policy, the vessels are manned under articles of employment, many of them customary European articles which conform to standards established by international convention, ${ }^{116}$ governing all aspects of working conditions and wages. ${ }^{116}$ Moreover, application of the American labor statutes to activities on flag-of-convenience ships on the basis of American ownership would logically lead to their application on board the large number of American-owned ships flying European flags; ;17 indeed, failure so to apply the acts would seem inconsistent with the nondiscrimination clause of commercial treaties with the flag-of-convenience states Liberia and Honduras. ${ }^{118}$ These European-flag vessels are governed by extensive labor legislation ${ }^{110}$ which may provide for administrative control of the bargaining process, prescribe exclusive rights and remedies available to the shipowners and crews, regulate the internal affairs of unions representing the crews, and may favor the unions and seamen of the flag state.

No expression of congressional intent exists thus to invade the internal economy of flag-of-convenience vessels. ${ }^{120}$ And, since even American-owned

114. See note 3 supra.

115. The Seamen's Articles of Agreement Convention was adopted at the International Labor Conference, 9th Session, at Geneva on June 24, 1926, and became effective on July 7 , 1938. Most of the maritime nations of Europe have adopted this convention, which regulates the terms and effects, and interpretation of seamen's articles. See $6 \mathrm{~A}$ BE:inorct 647 (7th ed. 1958). A detailed, far reaching convention is the Convention No. 92, Concerning Crew Accommodation on Board Ship, adopted by the International Labor Organization at its 32d Session in Geneva, June 8, 1949. The convention became effective Jan. 29, 1953, and most of the maritime nations of Europe are signatories. The United States is not, apparently on the premise that its existing regulations "equal or exceed" those of the convention. See 6 id. at 133. Convention No. 93, Concerning Wages, Hours of Work on Board Ship, and Manning, adopted by the International Labor Organization a month aiter Convention No. 92, and revised in 1957, has not yet received sufficient ratification to make it effective. None of the European nations has signed it, except Sweden, which exempted from its ratification the wages section of the convention adopted at the United Nations' specialized agency's 1958 conference. See 6A id. at 717; N.Y. Times, Oct. 25, 1959, $\S 5$, p. 17, col. 6. See generally Director-General, International Larour Office, Refost to INTERNATIONAI Labour CONFERENCE, 41st SEss., at 28-36 (1958).

116. See Brief for Plaintiffs (affidavit), Afran Transp. Co. v. National Mraritime Union, 169 F. Supp. 416 (S.D.N.Y. 1958). Typical articles employed were those of Italy, the Netherlands, and West Germany.

1.17. As of June 30,1959 , United States companies and their affiliates had registered 162 vessels, totalling $1,896,043$ gross tons under the flags of the United, Kingdom, the Netherlands, France, Norway, Germany, Belgium, Denmark, Italy and Finland. See Sum:mary of Oceangoing Vessels.

118. See notes 106-07 supra and accompanying text.

119. See, e.g., Merchant Shipping Act, 1894, 57 \& 58 Vict. c. 60, $\$ \$ 113-24,225$; Mferchant Shipping Act, 1906, 6 Edw. 7, c. 48, § 25 \& First Schedule; Mrerchant Shipping Act, 1948, 11. \& 12 Geo. 6, c. 44, \$\$ 1-3; Trade Disputes Act, 1906, 6 Edw. 7, c 47, \$\$ 2-4.

120. The statute is, therefore, distinguishable from the few instances, notably the sesmen's wage cases, in which specific congressional intent was found. See notes 64-67 supro and accompanying text. 
flag-of-convenience vessels are almost always manned by wholly alien crews, ${ }^{121}$ application of American labor legislation on shipboard would run counter to statements in Benz that the relevant congressional history "inescapably describes the boundaries of the [Taft-Hartley] Act as including only the workingmen of our own country and its possessions." 122 Furthermore, Bcnz gives no indication that American nationality of the vessel's ultimate owners has any bearing upon the jurisdictional reach of the statute. Indeed, since neither the lower court nor the Supreme Court inquired in its opinion into the nationality of the stockholders of the Panamanian corporation which operated the Liberian-flag ship, their nationality seems irrelevant to the rationale of the decision. ${ }^{123}$ In addition, application of American labor legislation aboard these vessels might lead to retaliation and protest by foreign states, particularly the flag state, which have exclusive interests in the vessel despite American ownership.

In sum, NLRB assertion of jurisdiction over employer-employee relations aboard American-owned flag-of-convenience vessels would constitute a breach of the principles of comity embodied in international law. An argument might be made that the United States' exclusive interest in the welfare of American labor, as expressed in the labor statutes, might be fostered by such an assertion of jurisdiction and thus justify the probable interference with foreign exclusive interests. But, although some interests exist which override comity considerations, ${ }^{124}$ the welfare of native seamen does not seem to fit into that category, since it is unclear whether that interest even overricles other American exclusive and inclusive interests which could be damaged by application of the labor acts aboard flag-of-convenience ships. Application might deter entry of the affected vessels to United States ports and thus injure the inclusive interest in international commerce, or may force American owners either to transfer the vessels to other foreign flags or to sell them, and thus undermine exclusive interests in a merchant marine readily available for defense purposes and/or in protecting American investments. In addition, even the exclusive interest in United States labor might be impinged upon if NLRB jurisdiction over flag-of-convenience vessels led first to similar jurisdiction over all American-owned foreign-flag ships, and then to retaliatory application of foreign labor laws in foreign ports.

\section{Remedies Against American Union Picketing on Shore}

$$
\text { Applicability of the Taft-Hartley Act }
$$

Shoreside picketing of foreign-flag ships by American unions has given rise to several shipowner suits for monetary and injunctive relief in both state and

121. See Brief for Plaintiff (affidavit), Afran Transp. Corp. v. National Maritime Union, 169 F. Supp. 416 (S.D.N.Y. 1958).

122. 353 U.S. 138, 144 (1957).

123. See note 74 supra and accompanying text.

124. See notes 55-60 supra and accompanying text. 
federal courts. ${ }^{125}$ Since the United States is obliged to furnish the owners of foreign-flag ships access to a forum on an equal footing with American-flag operators, ${ }^{126}$ the first issue raised by this litigation is whether such picketing is "arguably subject" to sections 7 ("rights of employees") or 8 ("unfair labor practices") of the national labor acts. ${ }^{127}$ If so, even though Taft-Hartley does not regulate labor relations on shipboard, it would provide exclusive remedies against shoreside picketing. ${ }^{128}$

Such a distinction between Taft-Hartley's applicability to an employer's relations with his own employees on one hand and his contacts with outside unions on the other comes from Local 25, Int'l Bhd. of Teansters $v$. New York, N.H. \& H.R.R., [The Piggy-Back Case], ${ }^{120}$ decided in 1956. There, the Supreme Court held that a railroad, whose labor relations were governed by the Railway Labor Act ${ }^{130}$ and not by Taft-Hartley, must nonetheless seek relief exclusively under Taft-Hartley from concerted activity (arguably protected or prohibited under sections 7 or 8 ) by the Teamsters, who, attempting to prevent the railroad from carrying truck trailers "piggy back" on flat cars, boycotted trailer delivery. And, in Moore Dry Dock, ${ }^{131}$ a drydock owner sought relief from the NLRB to end American union picketing of a Liberianflag vessel undergoing repair. The Board accepted jurisdiction and determined whether the picketing was prohibited by Taft-Hartley, even though it had decided in an earlier case ${ }^{132}$ that regulating employer-employee relations on board the same ship was beyond the jurisdictional scope of the act.

The majority opinion in Benz, ${ }^{133}$ however, failed to make any distinction between Taft-Hartley regulation of shipboard labor relations and the use of Taft-Hartley to give a remedy against shoreside American picketing. The Court emphasized that the case arose from a shipowner-crew dispute, ${ }^{134}$ and

125. Federal court cases have resulted in the following reported opinions: Benz $\forall$ Compania Naviera Hidalgo, S.A., 353 U.S. 138 (1957) ; Marine Cooks v. Panama S.S. Co., 265 F.2d 780 (1959); Afran Transp. Co. v. National Mraritime Union, 169 F. Supp. 416 (S.D.N.Y. 1958) ; Fianza Cia. Nav. S.A. v. Benz, 37 CCH Lab. Cas. 66733 (D. Ore. 1958). See also N.Y. Times, Jan. 14, 1960, p. 66, col. 1 (new suit against Int'l Mfaritime Workers). State court opinions, though unreported, have been noted in the press. See, e.g., id., Dec. 4, 1958, p. 78, col. 1 .

126. See, e.g., Treaty of Friendship, Commerce and Navigation With Liberia, Aug. 8, 1938, 54 Stat. 1739, T.S. No. 956; Treaty of Friendship, Commerce and Consular Rights With Honduras, Dec. 7, 1927, 45 Stat. 2618, T.S. No. 764; Freearax, Tue Isteknsatiosial Responsibility of States for Denial of Justice 215-16 (1938); Wilson, Acecss-10Courts Provisions in United States Commercial Treaties, 47 Aar. J. Ixr'L LL 20 (1953).

127. National Labor Relations Act $\S \S 7,8($ b), as amended, 61 Stat. 140 (1947), 29 U.S.C. $\S \S 157,158(\mathrm{~b})$ (1958).

128. "[W]hen an activity is arguably subject to $\S 7$ or $\S 8$ of the Act, the States as well as the federal courts must defer to the exclusive competence of the National Labor Relations Board." San Diego Bldg. Trades Council v. Garmon, 359 U.S. 236, 245 (1959).

129. 350 U.S. 155 (1956).

130. 44 Stat. 577 (1926), as amended, 45 U.S.C. $\$ \$ 151-88$ (1952).

131. Sailors' Union (Moore Dry Dock Co.), 92 N.L.R.B. 547 (1950).

132. Compania Maritima Sansoc, Ltd., 2 CCH LAB. L. REp. I 100S1 (fth ed. 1950).

133. Benz v. Compania Naviera Hidalgo, S.A., 353 U.S. 138 (1957).

134. Id. at $142-43$. 
seems to have concluded that a remedy against the picketing unions, whose aid had been enlisted by the crew, was inextricably linked with shipboard labor relations. ${ }^{135}$ Such a reading explains the Court's otherwise inapposite discussion of the principles of comity governing a coastal state's exercise of jurisdiction on board foreign-flag vessels. ${ }^{136}$ It also provides an arguable distinction from The Piggy-Back Case in which the Court emphasized that the Teamsters' activities were "unrelated" to the admittedly exempt relations between the railroad and its employees. ${ }^{137}$ But the maritime union's objective of enhancing job opportunities by curtailing the flag of convenience system is comparable to the Teamsters' objective of retaining employment opportunities for its truckdriver members by curtailing the piggy-back system; if the latter was subject to sections 7 or 8 , so is the former. By sidestepping Piggy$B a c k$, which it neither cited nor discussed, the Court ignored the contention of both the union ${ }^{138}$ and the dissenting Justice ${ }^{130}$ that NLRB remedial jurisdiction should have been exclusive even if Taft-Hartley were inapplicable to shipowner-crew relations. The Court's equating NLRB shoreside remedy with NLRB shipboard regulation, and deciding both under principles of comity, relieved it of the necessity of spelling out the reasons for holding that state remedies were not preempted by Taft-Hartley and for thus avoiding the thrust of The Piggy-Back Case. But the Court apparently relied on the existence of a preexisting shipowner-crew dispute to make this equation. Therefore, whether the same decision would be appropriate in a more typical future case not arising from such a dispute was left unanswered, and Benz must be examined to ascertain whether the shipboard dispute was crucial to the decision.

It might be argued that Benz represents a blanket refusal, in flag-of-convenience picketing cases, to subject unions to Taft-Hartley sanctions when they have no countervailing Taft-Hartley rights against the employer. This argument would stress the fact that the act envisions a continuing employeremployee relationship and provides rights and remedies for both sides tailored to create a favorable climate for collective bargaining, and might further assert that when the built-in restraints inherent in a continuing economic relationship are absent, as in the case of picketing an oceangoing vessel, the act's remedies are inadequate or inappropriate. In addition, labor relations on stuch vessels are governed by foreign laws and articles of employment, ${ }^{140}$ whereas the plaintiff in Piggy-Back was subject to obligations imposed by the Railway Labor Act, which, as part of the same national labor policy, are similar to

135. See id. at $146-47$.

136. Ibid.; see notes 73-77 supra and accompanying text.

137. Local 25, Int'l Bhd. of Teamsters v. New York, N.H. \& H.R.R., 350 U.S. 155, 159 (1956).

138. Reply Brief for Petitioners, pp. 6-7, Benz v. Compania Naviera Hidalgo, S.A. 353 U.S. 138 (1957).

139. 353 U.S. at 147 (dissenting opinion of Douglas, J.).

140. See notes 116,119 supra and accompanying text. 
those imposed by Taft-Hartley. ${ }^{141}$ But arguments such as these fail to explain Benz. It would be strange to base a ruling that state sanctions are not preempted by Taft-Hartley-and therefore may be imposed upon unions-on a theory that to impose NLRB sanctions on them would be to violate TaftHartley's scheme of mutuality of rights and remedies. More important, a continuing employer-employee relationship is, in fact, not a prerequisite to obtaining relief under the national act; any affected secondary employer, such as the dry dock operator in Moore, ${ }^{142}$ or, for that matter, perhaps anyone, ${ }^{113}$ may bring an unfair-labor-practice complaint. It is therefore essential to look elsewhere for the underlying rationale of Benz.

It might be argued that the Court in Benz based its decision on a theory of comity among nations relevant to union action against foreign-flag vessels but not against domestic railroads. Such an argument would proceed from two assumptions: First, that Taft-Hartley would deny the picketed shipowner relief available to him under tort law, ${ }^{144}$ which would be applicable to the picketing were the national act not accorded preemptive effect; second, that a failure to grant relief would constitute a governmental interference with the

141. See Virginian Ry. v. System Fed'n No. 40, Ry. Employees Dep't, 300 U.S. 515, 553 (1937) ("[The act's] provisions are aimed at the settlement of industrial disputes by" the promotion of collective bargaining. ..."); Note, 68 Y ALE L.J. 77, $80 \mathrm{n.9}$ (1958) (collecting authorities).

"The purposes of [the Railway Labor Act as amended] . .. are: (1) To avoid any" interruption to commerce or to the operation of any carrier engaged therein; (2) to forbid any limitation upon freedom of association among employees or any denial, as a condition of employment or otherwise, of the right of employees to join a labor organization;... (4) to provide for the prompt and orderly settlement of all disputes concerning rates of pay, rules, or working conditions; ...."

48 Stat. 1186 (1934), 45 U.S.C. \& 151 (a) (1952).

142. See Sailors' Union (Moore Dry Dock Co.), 92 N.L.R.B. 547 (1950).

143. See National Labor Relations Act § 10(b), as amended, 61 Stat. 146 (1947), 29 U.S.C. $\S 160(\mathrm{~b})$ (1958) ("Whenever it is charged that any person has engaged in . . . any ... unfair labor practice ...."). (Emphasis added.) But cf. Sailors' Union, supra note 142 (reference to "person aggrieved" as filing party).

144. While the national labor act provides expeditious procedures by which the Labor Board may obtain a court injunction pursuant to a certain unfair labor practice charge, see Labor-Management Relations Act $\S 10(l), 61$ Stat. 149 (1947), 29 U.S.C. $\S 160(l)$ (1958) ; Note, 69 YALE L.J. 309, 319 n.64 (1959), a procedure almost as rapid as dircet application to a federal court, compare Fen. R. Crv. P. 65(b), the Board may so act only when it has "reasonable cause" to believe that an unfair labor practice has been committed. Damages are available under Taft-Hartley only if the union is held to have committed a § 8(b) (4) unfair labor practice. See Labor-Management Relations Act \& 303, 61 Stat. 158 (1947), 29 U.S.C. \& 187 (1958), as amended, 73 Stat. 545 (1959) (damages available in federal courts). Of course, the NLRB's power to issue cease and desist orders and to take "such affirmative action ... as will effectuate the policies of this Act" requires unfair labor practice findings. See National Labor Relations Act $\S 10(c)$, as amended, 61 Stat. 147 (1947), 29 U.S.C. $\$ 160$ (c) (1958). Hence, if the picketing were not an unfair labor practice, preemption would be tantamount to precluding all relief. 
internal economy of the vessel. ${ }^{145}$ This theory offers one explanation for the Court's concluding reference to the possibilities of "international discord" and "retaliative action." ${ }^{46}$ Nonetheless, even if holding Taft-Hartley preemptive would deny foreign-flag shipowners relief and thus have adverse effects upon foreign shipping, this theory probably does not justify a broad reading of Benz. Since picketing of flag-of-convenience vessels is undertaken by private parties, injury to foreign exclusive interests probably may not be charged to a positive exercise of jurisdiction by the United States. ${ }^{147}$ The situation is therefore distinguishable from application of Taft-Hartley to shipboard activities, which would put the full power of the United States-as sovereign coastal state-behind union efforts to organize the vessel. And remedying shoreside picketing exclusively under Taft-Hartley would not displace the law of the flag state; the issue is determining applicable United States law rather than resolving a conflict with foreign law. Withholding a state remedy against picketing results in no change in the law governing the vessel, does not interfere with existing contractual or bargaining relationships on shipboard, and, therefore, does not invade the internal economy of the vessel within the normal contemplation of that doctrine. ${ }^{148}$ And, as a general proposition, the availability of remedies for particular litigants should not be determinative of the act's jurisdictional scope. So long as foreign shipowners have access to United States tribunals for remedies equal to those forthcoming to United States-flag shipowners, they should not be able to invoke international law principles or treaty obligations to allow them greater protection. In those circumstances where relief is forthcoming only when one union has received Board certification, ${ }^{149}$ a foreign-flag shipowner who recognizes an American union but is denied certification by NLRB refusal to assume jurisdiction over shipboard relations might be denied a Taft-Hartley remedy available to his

145. Union picketing might prevent the foreign-flag vessels from docking if accomplished, as in Marine Cooks v. Panama S.S. Co., 265 F.2d 780 (9th Cir. 1959), by picket ships in the harbor. Or, once docked, the vessels could be kept from discharging or loading cargoes and from departing. Delay in delivery or loading might cause shippers to breach delivery date clauses in sales contracts, or charterers to breach such provisions in contracts of aff reightment. Time charterers might be forced to pay overlap at higher rates, and extra crew and maintenance costs would have to be paid. See The Rygya, 161 Fed. 106, 107 (2d Cir. 1908). These costs could accrue to the shipowner or charterer and, if the threat of picketing were persistent, might in practice bar his entering United States ports. Although the unions may now be deterred by the damage awards in both Benz and Panama, preemption might remove such deterrence and lead to more widespread and disruptive picketing.

146. 353 U.S. at 147.

147. Cf. Briggs 711-13; Eagleton, The Responsibility of States in International. LAw 82-85 (1928).

148. Cf. note 93 supra and accompanying text (Jones Act). Nor would private picketing seem to infringe the "liberty freely to come" clauses of commercial treaties. See note 107 supra and accompanying text.

149. E.g., Labor-Management Relations Act \& 8(b) (4)(c), 61 Stat. 141 (1947), 29 U.S.C. $\S 158(b)(4)(c)(1958)$. 
American-flag counterparts. But this situation is too remote to justify holding the act inapplicable to all shoreside picketing.

Since these alternative explanations of the Bcnz decision seem untenable, it must be concluded that the preexisting shipboard dispute was crucial to the rationale of that opinion. Therefore, $B e n z$ is probably inapposite authority for flag-of-convenience picketing cases which do not have a similar link with shipboard labor relations. And, even when such a dispute exists, the Benz decision to allow remedies against the picketing in accordance with state law, while denying NLRB remedies because of a reluctance "to run interference in . . . a delicate field of international relations," 150 is questionable. The Court's placing shipboard labor relations beyond the scope of American labor legislation was proper under principles of comity. But why the Court apparently felt that federal remedies would lead to involvement in "disputes between nationals of other countries operating ships under foreign laws,"151 while state remedies would not, is unclear. The Court might have believed that granting a state remedy against picketing would not of itself constitute an interference with shipboard activities, but that invocation of Taft-Hartley remedies ashore would logically lead, either in Benz itself or in future cases, to establishment of TaftHartley regulation aboard. Such a fear could have been dispelled, however, by an express disclaimer in the opinion. Nore likely, the Court was of the opinion that, since the crew asked the union to represent them in the controversy with their employer, the union was not acting as an American union, but rather as the spokesmen of a foreign crew, ${ }^{162}$ and that the entire complex of facts constituted a shipowner-crew dispute arising out of the internal order of the vessels. But if it did, it would follow that remedies against picketing, like other aspects of the dispute, were governed by the law of the flag state and were under the exclusive jurisdiction of the flag state's consul. ${ }^{103}$

In any event, if Benz is authority only for cases involving preexisting shipboard disputes, the federal preemption doctrine, as evidenced in The PiggyBack Case, ${ }^{154}$ would probably apply in most employers' actions for remedies against flag-of-convenience picketing. No extrastatutory reasons exist to take peaceful picketing by United States unions which are "labor organizations"

150. 353 U.S. at 147.

151. Id. at 143 .

152. See id. at 140 .

153. See notes 101-05 supra and accompanying text. If the dispute was regarded as one "concerning the adjustment of wages and the execution of contracts relating thereto," rather than one "arising out of the internal order," the consul will have jurisdiction cuncurrent with that of "local authorities." See text following note 105 supro. But this wuuld not exclude the NLRB while including state courts.

The shipboard dispute in Bens could be placed in either of these pigeonholes. The iarts involved shipboard refusal to obey the Mlaster's orders, 353 U.S. at 139, claims af "filthy conditions ... and contaminated food," id. at 139 n.?, and a demand that the Master "bargain with them [the crew] on wages and conditions," ilid.

154. See notes $129-30$ sipra and accompanying text. 
composed of "employees"155 under the act beyond the act's ambit. Shipowners may argue that preemption would lead to uncontrolled picketing which would, in turn, threaten their competitive position and thus interfere with foreign investment and with defense requirements of a ready merchant marine. ${ }^{160}$ But only a specific expression of congressional intent, rather than congressional acquiescence in ship transfers, would seem sufficient to support an interpretation of United States exclusive interests which might abrogate the national labor act's explicit guaranty of the right to concerted activity for mutual aid or benefit. ${ }^{157}$

If Taft-Hartley preempts state relief, the question arises whether American union picketing of flag-of-convenience vessels is an unfair labor practice under section $8(\mathrm{~b})$ of that act. ${ }^{158}$ Nonviolent picketing would constitute an 8 (b) (4) secondary boycott under NLRB v. Denver Bldg. Trades Council, ${ }^{160}$ decided in 1951, if one, even if not its only, purpose was found to be the use of economic force against secondary employers-such as stevedore or drydock companies-or their employees rather than the primary employer, the flag-ofconvenience shipowner. Since all picketing not confined to employee entrances will affect secondary employers dealing with the employer picketed, and since "purpose" is difficult to prove, the NLRB, followed by a line of court of appeals decisions, attempted, in Moore Dry Dock, ${ }^{160}$ to fashion a workable rule to govern such cases: picketing as near the situs of a primary employer as circumstances allow is not a secondary boycott if the public is informed that the dispute is solely with the primary employer. Under this rule, therefore, flag-of-convenience picketing can be immune from 8 (b) (4) provided these conditions are met, even though stevedores and dry dock companies are prevented from dealing with the picketed ship.

If, on the other hand, "an object" of the picketing is organization of the crews of flag-of-convenience vessels, it might arguably constitute organizational picketing, which, in certain circumstances, is an unfair labor practice under Taft-Hartley section 8(b) (7), added in 1959.101 For example, when

155. See National Labor Relations Act $\S 2(3)$, (5), as amended, 61 Stat. 137 (1947), 29 U.S.C. $\$ \S 152(3),(5)(1958)$.

156. See text following note 124 supra.

157. National Labor Relations Act $\S 7$, as amended, 61 Stat. 140 (1947), 29 U.S.C. $\S 157$ (1958).

158. Labor-Management Relations Act $\S 8($ b), 61. Stat. 141 (1947), 29 U.S.C. \& 158 (b) (1958).

159. 341 U.S. 675 (1951).

160. Sailors' Union (Moore Dry Dock Co.), 92 N.L.R.B. 547 (1950); see Seaftrers Int'l Union v. NLRB, 265 F.2d 585, 589 (D.C. Cir. 1959) (collecting court of appeals cases).

161. Labor-Management Relations Act $\S 8($ b) (7), added by Labor-Management Reporting \& Disclosure Act of 1959, No. 86-257, $\$ 704(c)$, 73 Stat. 544.

The unions might try to escape the unfair labor practice charge by disclaiming any intent to organize the vessels. This was the union strategy in Marine Cooks v. Panama S.S. Co., 265 F.2d 780 (9th Cir. 1959). See Reply Brief of Appellants, p. 6. The unions cannot picket foreign-flag ships to force a discharge of their alien crews because such discharge, 
a union does not file, within thirty days of its organizational picketing, a representation petition requiring the NLRB to hold a representation election, its

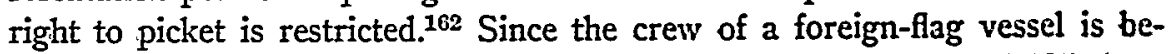
yond the regulatory scope of the act, it would seem impossible to fulfill these requirements: a valid representation petition could not be filed nor a valid election held. Hence, an unfair labor practice could never be held to have occurred. Organizational picketing is also an unfair labor practice if the picketed employer's employees have already designated a certified bargaining representative, or have, within the preceding year, participated in a valid representation election. ${ }^{163}$ While the crews of flag-of-convenience vessels could not do either, some flag-of-convenience vessels may be organized by foreign seamen's unions which are recognized by foreign law, ${ }^{104}$ and it might be argued that such prior organization should be viewed as the equivalent of NLRB certification for purposes of giving rise to an unfair labor practice.

\section{Applicability of the Norris-LaGuardia (Anti-Injunction) Act}

If, however, Benz is broadly read, and Taft-Hartley never given preemptive effect in flag-of-convenience picketing cases, a shipowner seeking injunctive relief in federal court will face the additional hurdle of the Norris-LaGuardia Act, which provides that no federal court has jurisdiction to issue an injunction "in a case involving or growing out of a labor dispute."16s The act defines a labor dispute broadly to include "any controversy concerning terms or conditions of employment... regardless of whether or not the disputants stand in the proximate relation of employer and employee."100 Because of the concluding clause of this definition, the Supreme Court has held that picketing by a Negro organization, not a labor union, to force an employer to hire Negro clerks is a protected labor dispute. ${ }^{107}$ Thus, even if the American unions are not the representatives of the alien crews, and are barred from being certified as such in the future, their efforts to "discourage the further transfer of vessels to foreign flags ... [to arouse] public opinion, ... [ [and to raise] the standards aboard foreign flag vessels"168 would seem to constitute

without the prior consent of the Attorney General, would be illegal, see Immigration \& Nationality Act $\S 256,66$ Stat. 223 (1952), \& U.S.C. $\$ 1286$ (1958), and a strike to force commission of an illegal act is itself illegal, see NLRB v. Indiana Desk Co., 149 F.2d 987 (7th Cir. 1945). See also American News Co., 55 N.L.R.B. 1302 (1944). Nor can unions legally picket to force an immediate change in seamen's articles of employment. See Benz v. Compania Naviera Hidalgo, S.A., 233 F.2d 62, 64, 66 (9th Cir.), cerl. denied, 352 U.S. 890 (1956) ; cf. Rees v. United States, 95 F.2d 784 (4th Cir. 1938).

162. Labor-Management Reporting \& Disclosure Act of 1959, No. \$6-257, § 704(c),

73 Stat. 544.

163. Ibid.

164. See N.Y. Herald Tribune, Oct. 22, 1959, p. 47, col. 1.

165. 47 Stat. 70 (1.932), 29 U.S.C. $\$ 101$ (1958).

166. 47 Stat. 73 (1932), 29 U.S.C. \& 113 (1958).

167. New Negro Alliance v. Sanitary Grocery Co., 303 U.S. 552 (1938).

168. See Afran Transp. Co. v. National Maritime Union, 169 F. Supp. 416, 423 (S D. N.Y. 1958). 
a Norris-LaGuardia labor dispute with the shipowners. It could be alternatively contended that flag-of-convenience picketing does not concern "terms or conditions of employment" under the act, on the ground that unbridled union exertion of economic power within the territorial limits of the United States to prevent employers from making foreign investments and realizing labor cost savings of operating abroad are not protected by Norris-LaGuardia. Union picketing to force flags-of-convenience vessels under United States registry, from which most have been transferred according to statute, is not a legitimate labor objective, the argument would run, since decisions to fly foreign flags and to invest abroad lie within the prerogatives of management. ${ }^{169}$ Such a restricted definition of "terms and conditions of employment" finds adequate support, however, in neither legislative intent ${ }^{170}$ nor previous cases. ${ }^{171}$ So long as the management decisions sought to be reversed are reasonably related to employment opportunities, union picketing has been held covered by the act. In the most relevant Supreme Court case, ${ }^{172}$ a cutrate system of marketing milk-the "vendor system"-allowed a group of dairies employing nonunion labor to undercut dairies employing union drivers in making door-to-door deliveries. Because the vendor system was making inroads into the job opportunities of union drivers, the union picketed retail outlets supplied through the vendor system in an attempt either to force abandonment of that system or to impose union wage standards on vendor system personnel. The Court found that a "labor dispute" existed and that an injunction was barred by Norris-LaGuardia. And, the Second Circuit, in Aetna Freight Lines, Inc. v. Clayton, ${ }^{173}$ found that teamsters picketing of the terminal of a trucking firm which leased trucks from their owner-drivers to force the firm to conform its lease agreements to other firms' contracts with their union drivers involved a "labor dispute."

169. See Memorandum in Support of Plaintiff's Application for Temporary Injunction, p. 7, Afran Transp. Co. v. National Maritime Union, Civil No. 140-156, S.D.N.Y., 1958.

170. See United States v. Hutcheson, 312 U.S. 219 (1941).

171. The Afran Memorandum cited two cases for the proposition that the seamen's unions' activity is "not a labor objective or the subject of a labor controversy." But neither supports the point for which it was introduced. In Bakery Sales Drivers Union v. Wagshal, 333 U.S. 437 (1948), the Court found a dispute between "two businessmen." Streiffer v. Seafarers Sea Chest Corp., 162 F. Supp. 602 (E.D. La. 1958), was a private antitrust action by a merchant against a union which was acting as a commercial enterprise. In a more relevant case, Brotherhood of R.R. Trainmen v. New York Cent. R.R., 246 F.2d 1.14 (6th Cir. 1957), a railroad's decision to close a railroad yard was held not to have created a labor dispute because the possible loss of jobs was only "anticipatory." But this case offers no support for shipowners in the normal flag-of-convenience picketing case, where the alleged loss of jobs caused by the shipowners' decision to transfer to foreign registry has already occurred.

172. Milk Wagon Drivers' Union v. Lake Valley Farm Prods., Inc., 311 U.S. 91 (1940).

173. 228 F.2d 384 (2d Cir. 1955). 
In Marine Cooks v. Panama S.S. Co., ${ }^{174}$ the Ninth Circuit, relying on a broad construction of Benz, ruled Norris-LaGuardia inapplicable to flag-ofconvenience picketing cases. ${ }^{175}$ The Court apparently regarded Norris-LaGuardia as a substantive labor relations statute similar in scope to Taft-Hartley. ${ }^{176}$ But Norris-LaGuardia may be jurisdictionally broader. While TaftHartley is a comprehensive scheme setting forth mutual employer-employee rights and remedies, Norris-LaGuardia, on its face, is a limitation of the power of the federal judiciary to grant injunctive relief in all kinds of labor disputes, no matter what the context. ${ }^{17 i}$ Therefore, even a reading of Benz which declares Taft-Hartley inapplicable to any foreign-flag case does not necessarily place a similar limitation on Norris-LaGuardia.

\section{Jurisdiction of Courts}

If, however, both Taft-Hartley and Norris-LaGuardia (and with the latter, its various state versions), ${ }^{178}$ are held inapplicable to flag of convenience picheting, state and federal courts would be free to award whatever relief state law may afford. In such circumstances, a holding, analogous to $B \mathrm{enz}$, that the granting of state relief would constitute an unreasonable interference with foreign commerce would seem impossible; indeed established principles of international law and United States treaty obligations guarantee aliens access to a forum for redress of wrongs in accordance with local law. ${ }^{170}$

\section{Federal Courts: Diversity Jurisdiction}

Normally, a shipowner would be able to initiate his suit in a federal district court-or the defendant union may be able to remove it there-under the grant of diversity jurisdiction. ${ }^{180}$ But the requisite proof of diversity of citizenship between all plaintiffs and all defendants may pose problems in a minority of states. Because seamen's unions are unincorporated associations, ${ }^{181}$

174. 265 F.2d 780 (9th Cir. 1959).

175. Contra, Afran Transp. Co. v. National Maritime Union, 169 F. Supp. 416 (S.D. N.Y. 1958). Although Fianza Cia. Nav. S.A. v. Benz, 37 CCH Lab. Cas. 66733 (D. Ore. 1958), held that no labor dispute existed, the unions had apparently coneeded that they were not in dispute with the owner; indeed, "perhaps, they picked the wrong vessel in this case." Id. at 66736 .

176. 265 F.2d at 786-87.

177. See Milk Wagon Drivers' Union v. Lake Valley Farm Prods., Inc., 311 U.S. 91, 101 (1940).

178. E.g., Conn. Gen. Stat. $\S \S 31-112$ to -119 (1958); MAss. Ans. Laws ch. 214,

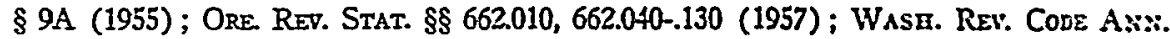
$\$ \S 49.32 .011-.910$ (1958); see 2 TELLER, Labor Disputes aNd Collective Bafgaisisg $\S 434$ (1940) ; 46 COLUM. L. REV. 860, 861 n.6 (1946) (collecting statutes).

179. See note 126 sipra.

180. 28 U.S.C. $\S 1332$ (1958).

181. See, e.g., Record, p. 14, Benz v. Compania Naviera Hidalgo, S.A., 353 U.S. 138 (1957) (Sailors' Union of the Pacific) ; Record, p. 3, Marine Cooks v. Panama S.S. Co., 
they are generally considered not to possess a single citizenship. ${ }^{182}$ Although some states have enacted statutes permitting suit against unions as entities, ${ }^{183}$ proof of citizenship diverse from that of every member of the defendant union is required. ${ }^{184}$ Since a seamen's union may have several thousand members, ${ }^{186}$ proof of citizenship of every member may be impossible to obtain and would often reveal that, since the union has resident alien members, such diversity does not exist. ${ }^{186}$ In practice, therefore, the shipowner can bring a diversity suit in a federal court only by means of a class action. Although a class action against a seamen's union local would be proper under rule 23(a) of the Federal Rules of Civil Procedure, a recent Third Circuit case ${ }^{\mathbf{1 8 7}}$ could be read to indicate that rule $17(\mathrm{~b})$, which provides that "capacity to stue or be sued shall be determined by the law of the state," bars such an action in district courts located in a state where class actions against unions are not allowed by statute or by decision. ${ }^{188}$ But even if this severely criticized case ${ }^{180}$ is followed, class actions against unions are possible in most coastal states handling an appreciable amount of foreign-flag tonnage. ${ }^{100}$ Shipowner actions for

265 F.2d 780 (9th Cir. 1959) (Marine Cooks \& Stewards, AFL; Seafarer's Int'l Union of North America).

182. See Kaplan, Suits Against Unincorporated Associations Under the Federal Rulcs of Civil Procedure, 53 MTCH. L. Rev. 945, 950-51 (1955) ; Note, 68 Y ALE L.J. 1182, 118384 (1959). But see American Fed'n of Musicians v. Stein, 213 F.2d 679, 685-88 (6th Cir.), cert. denied, 348 U.S. 873 (1954); Comment, 66 YALE L.J. 712, 742 n.174 (1957) (collecting cases).

183. See, e.g., Conn. Gen. Stat. § $52-76$ (1958) ; Del. Code Ann. tit. 10, § 3904 (1953) ; N.J. Stat. Ann. \& 2A:64-1 (1952).

184. See Hettenbaugh v. Airline Pilots Ass'n, 189 F.2d 319 (5th Cir. 1951.) ; Lloyd A. Fry Roofing Co. v. Textile Workers, 149 F. Supp. 695 (E.D. Pa. 1957); International Allied Printing Trades Ass'n v. Master Printers Union, 34 F. Supp. 178 (D.N.J. 1940).

185. See The World Almanac and Book of Facts 53 (1959). Although the shipowner may sue the union local, he would probably wish to join the international to ensure satisfaction of a claim for damages. Besides, the seaman's local may itself be too large to permit ready discovery of the citizenship of all its members.

186. See Ex parte Edeistein, 30 F.2d 636 (2d Cir.), cert. denied, 279 U.S. 851 (1929) (aliens, even of diverse nationality, are not of diverse citizenship under $\S 1332$ ). Although this was the stated reason why the plaintiff in Panama had disclaimed diversity jurisdiction, 265 F.2d at 782, such jurisdiction could have been established through the device of a class action, see note 190 infra.

187. Underwood v. Maloney, 256 F.2d 334 (3d Cir.), cert. denicd, 358 U.S. 864 (1958).

188. See Note, 68 Yale L.J. 1182, 1192 (1959) ; 107 U. PA. L. REv. 559, 561 (1959); Pennsylvania seems to be the only state where class actions against unions are definitely prohibited. See Lloyd A. Fry Roofing Co. v. Textile Workers, 149 F. Supp. 695 (E.D. Pa. 1957) ; PA. R. Crv. P. 2152, 2153; Note of Procedural Rules Committec to PA. R. Clv. P. 2230.

189. See Note, 68 YALE L.J. 1182, 1188-92 (1959) ; 107 U. PA. L. REv. 559, 562 (1959).

190. See, e.g., Pascale v. Emery, 95 F. Supp. 147 (D. Mass. 1951) ; Cross v. Oncida Paper Prods. Co., 117 F. Supp. 919 (D.N.J. 1954) ; Cal. Civ. Proc. Code Ann. \$ 382; N.Y. Gen. Ass'Ns Law $\S 13$; Wast. Rev. Code Ans. $\$ 4.08 .070$ (1956); Tex. R. Civ. P. 42. Even under a broad interpretation of Underwood v. Maloney, the federal district court in Panama would have been able to allow a diversity action against union members as 
injunctive relief will give rise to equity doctrines even more favorable to class actions, ${ }^{191}$ and may make practical suits against individual officers, rather than entire unions. On the other hand, state law may bar access to the union treasury for damage claims brought in a class action. ${ }^{102}$

\section{Federal Courts: Federal Question Jurisdiction}

If diversity jurisdiction is unavailable, a shipowner may attempt to establish federal court jurisdiction on other grounds. In Panama, the shipowner disclaimed diversity jurisdiction, and attempted to establish federal question jurisdiction under section 1331 of the Judicial Code. ${ }^{103}$ In a confusing opinion, the court stated that the cause of action was "based on interference with maritime traffic on navigable waters and on interference with the performance of a maritime contract constituting maritime torts," 104 governed by substantive law which is "basically federal."

By apparently viewing violations of the general maritime law as giving rise to federal question jurisdiction, the Ninth Circuit opinion misconstrued ${ }^{100}$ the Supreme Court's holding a few weeks earlier in Romero v. Intcrnational Terminal Operating Co. ${ }^{197}$ which held that the constitutional grant of judicial power sharply separated "admiralty and maritime" cases from cases "arising under" the laws of the United States. In the light of the saving-to-suitors clause, the fact that a cause of action would be cognizable in admiralty is insufficient to establish jurisdiction on the law-equity side of the court. ${ }^{108}$ Thus the latter jurisdiction would seem to arise only if the cause of action alleges a violation of statutory law, a treaty, or the Constitution.

Although the Ninth Circuit attempted to distinguish Romero by demonstrating that Panama was not a case of admiralty and maritime jurisdiction because the plaintiff sought an injunction, not only damages, ${ }^{100}$ the distinction is unconvincing. The court considered Panama a nonmaritime case because

representatives of a class, since Washington allows such actions. As damages are recoverable in Washington from the funds of an unincorporated association whose members are sued in a class action, see St. Germain v. Bakery Workers Union, 97 Wash. 282, 166 Pac. 665 (1917), the disclaimer of $\$ 1332$ jurisdiction in Panama is inexplicable.

191. In Florida, for example, class actions are possible only in equity. See FLA. R. Crv. P. 3.6.

192. See Benz v. Compania Naviera Hidalgo, S.A., 233 F.2d 62 (9th Cir.), ccrt. denied, 352 U.S. 890 (1956) (judgment against union members as a class unenforcible against union treasury under Oregon law).

193. 28 U.S.C. \& 1331 (1958).

194. 265 F.2d at 782.

195. Id. at 783.

196. See The Supreme Court, 1958 Term, 73 HARv. L. REv. 126, 141 (1959).

197. 358 U.S. 354 (1959).

198. Prior to Romero, the circuits had been split. Compare Doucette v. Vincent, 194 F.2d 834 (1st Cir. 1952), with Paduano v. Yamashita Kisen Kabushiki Kaisha, 221 F.2d 615 (2d Cir. 1955), and Jordine v. Walling, 185 F.2d 662 (3d Cir. 1950).

199. See 265 F.2d at 783-86. 
admiralty courts have traditionally refused to grant injunctive relief ;00 thus, it concluded, nothing had to be saved, no conflict with the saving clause existed, and law-equity jurisdiction was not barred. But, assuming that shoreside picketing can be considered a maritime issue, ${ }^{201}$ the case would not seem to fall outside admiralty jurisdiction since, as pointed out in a footnote to Romero, the type of remedy sought does not determine the scope of admiralty jurisdiction; and a case involving a maritime claim is within admiralty jurisdiction "regardless of the remedy sought."202 Nor does it follow that because an action is not admiralty it is law-equity. It might be argued-although the Panama court did not-that federal judicial power over all cases of admiralty and maritime jurisdiction, as provided by article III of the Constitution, is broader than the Judiciary Act's grant of admiralty and maritime jurisdiction to the federal courts. According to this argument, a residutum of cases exist which are beyond the jurisdiction of the federal courts sitting in admiralty but are still within the judicial power of the United States. ${ }^{203}$ But even if such a residuum of cases exists they are not necessarily cognizable under section 1331. The alternative possibility is equally tenable: Congress has not yet seen fit to exercise the full extent of its constitutional power and has left the federal courts without power to hear such a residuum of cases.

The Ninth Circuit attempted affirmatively to ground federal question jurisdiction on a "breach of a federal duty." 204 While the court did not inclicate the nature of this "federal duty," it may have contemplated cases in which federal question jurisdiction had been sought on the grounds of interference with interstate or foreign commerce. But the few cases in which such a contention was made have rejected it. ${ }^{205}$ Or, the circuit court may sub silentio have affirmed that part of the district court opinion finding an "impairment" of United States' international obligations ${ }^{200}$-apparently the commercial treaty with Liberia-as urged by the shipowner. But, since treaties are contracts between states, in the absence of specific language in the treaty 207 or

200. See Schoenamsgruber v. Hamburg Am. Line, 294 U.S. 454, 457 (1935) (dictum); Sound Marine \& Mach. Corp. v. Westchester County, 100 F.2d 360 (2d Cir. 1938), ccrl. denied, 306 U.S. 642 (1939) ; Paterson v. Dakin, 31 Fed. 682 (S.D. Ala. 1887) ; 4 BENEDICT $\S 613$, at 211 (6th ed. 1940). But see The Olga, 254 Fed. 439 (E.D.N.Y. 1918) (dictum). See generally Morrison, The Remedial Pozvers of the Admiralty, 43 YALE L.J. 1 (1933).

201. See notes 211-13 infra and accompanying text.

202. 358 U.S. at 367 n.23.

203. See 59 Colum. L. Rev. 946 (1959).

204. 265 F.2d at 785 .

205. See Brotherhood of R.R. Trainmen v. New York Cent. R.R., 246 F.2d 114 (6th Cir. 1947) ; Toledo, P. \& W.R.R. v. Brotherhood of R.R. Trainmen, 132 F.2d 265 (7th Cir. 1942), rev'd on other grounds, 321 U.S. 50 (1944); Postal Tel. Cable Co. v. Nolun, 240 Fed. 754 (D. Mont. 1917) ; Re Metropolitan Ry. Receivership, 208 U.S. 90 (1908) (dictum).

206. See Record, pp. 34-35, Marine Cooks v. Panama S.S. Co., 265 F.2d 780 (9th Cir. 1959) (unreported opinion of Boldt, J., Findings of Fact XIII and XVIII).

207. See Jurisdiction of the Courts of Danzig, P.C.I.J., ser. B, No. 15 (1928) (language found to give private parties cause of action). 
in separate legislation, ${ }^{208}$ they do not give a cause of action against private parties ${ }^{209}$ to aliens claiming rights under them. ${ }^{210}$

\section{Federal Courts: Admiralty Jurisdiction}

A shipowner might also attempt to establish jurisdiction on the admiralty side of a federal court on grounds that union picketing constitutes a maritime tort-interference with a maritime contract of affreightment. Under traditional admiralty doctrine, a tort is maritime only if it "occurs" on navigable waters, ${ }^{211}$ and according to accepted conflicts-of-law principles, a tort "occurs" where the harm is felt.212 But it is unclear where the harm derived from interference with a contract of affreightment is felt. Arguably, the harm is felt on shore at the point of nondelivery. Or, in the case of perishables, the harm might be held to have occurred in the hold of the vessel, on navigable vaters, where the goods deteriorated in value. Nevertheless, the usual rule which equates situs of tort with situs of injury seems inappropriate when the tort is interference with a maritime contract since, unlike a personal injury, for example, the harm is not felt at a single and easily ascertainable point. In-

208. See, e.g., Jordan v. Tashiro, 278 U.S. 123 (1928) where suit was brought in a state court under a California statute interpreted to grant a cause of action in state courts to aliens claiming rights under United States treaties. See Tashiro v. Jordan, 201 Cal. 236, 256 Pac. 545 (1927).

209. A cause of action against the Government, which has not been attempted in any of the flag-of-convenience picketing cases, would of course be possible only if the Government could be held to have waived its sovereign immunity. See O'Reilly de Camara r. Brooke, 209 U.S. 45 (1908) (dismissing suit, on sovereign immunity theory, brought under statute granting federal district courts jurisdiction over suits by aliens for tortious violation of treaty or the law of nations); 28 U.S.C. $\$ 1346$ (a) (2) (1958).

210. See Filhiol v. Maurice, 185 U.S. 108 (1902). A long neglected jurisdictional statute, 28 U.S.C. $\$ 1350$ (1958), grants federal district courts power to hear "any civil action by an alien for a tort only, committed in violation of the law of nations or a treaty of the United States." Although this statute has never been held to grant a cause of action, such interpretation might be possible. See O'Reilly de Camara v. Broole, 209 U.S. 45 (1908) (plaintiff's suit under $\S 1350$ against a United States Army officer, for deprivation of rights during the military occupation of Cuba was dismissed because of sovereign immunity, not because the statute is purely jurisdictional and creates no cause of action). See also Bolchos v. Darrel, 3 Fed. Cas. 810 (No. 1607) (D.S.C. 1795) (cause of action unclear).

211. See The Plymouth, 70 U.S. (3 Wall.) 20, 34-35 (1865); Forgione v. United States, 202 F.2d 249 (3d Cir. 1953) ; 1 Benedict $\$ 127$ (6th ed. 1940). The precise holding of The Plymouth, that the destruction of a wharf due to shipboard negligence was not a maritime tort because the injury was consummated on land, was reversed by 62 Stat. 496 (1948), 46 U.S.C. $\$ 740$ (1952), which extends the federal admiralty jurisdiction to such "amphibious torts."

212. "Ordinarily it is the locus of the tort which governs, and where the injury is on the water though the defendant's act was on the land, that locus is determined by the water." The Poznan, 276 Fed. 418, 433 (S.D.N.Y. 1921) (L. Hand, J.); Hermann v. Port Blakely Mill Co., 69 Fed. 646 (N.D. Cal. 1895); Restatrarent, CoNflicts $\$ 377$ (1934); Harper \& JaXres, Torts $\S 30.4$ (1956). See also The America, 34 F. Supp. 855 (E.D.N.Y. 1940). 
deed, the only relevant cases assume that the tort of interference occurs on navigable waters; "the injury must be maritime in its character as much as though the case sounded in contract .... [I]f that contract was maritime enough in its character to base a libel upon it in contract, the injury resulting from the wrongful act on shore was as maritime, because it was the same thing." 213 Moreover, the federal judge sitting in admiralty would seem to be better equipped than state court judges to fix damages in foreign-flag picketing cases, since factors peculiar to maritime commerce must be considered. And, while previous cases invoking admiralty jurisdiction for interference with maritime contracts were actions by shippers, ${ }^{214}$ a shipowner or charterer would also seem to have a cause of action. But even if admiralty jurisdiction is available, the shipowner may find such jurisdiction unattractive because injunctive relief ${ }^{215}$ would not seem possible.

213. The Poznan, supra note 212, at 433-34 (inducement of breach); accord, Sidncy Blumenthal \& Co. v. United States, 30 F.2d 247, 249 (2d Cir.), cert. denied, 279 U.S. 847 (1929) (deliberately wrongful transshipment of cargo; "If any tort be maritime, certainly this was one.") (L. Hand, J.).

214. See cases cited note 213 supra.

215. See note 200 supra. 